\title{
Epigenetic associations in relation to cardiovascular prevention and therapeutics
}

\author{
Susanne Voelter-Mahlknecht
}

\begin{abstract}
Cardiovascular diseases (CVD) increasingly burden societies with vast financial and health care problems. Therefore, the importance of improving preventive and therapeutic measures against cardiovascular diseases is continually growing. To accomplish such improvements, research must focus particularly on understanding the underlying mechanisms of such diseases, as in the field of epigenetics, and pay more attention to strengthening primary prevention.

To date, preliminary research has found a connection between DNA methylation, histone modifications, RNA-based mechanisms and the development of CVD like atherosclerosis, cardiac hypertrophy, myocardial infarction, and heart failure. Several therapeutic agents based on the findings of such research projects are currently being tested for use in clinical practice. Although these tests have produced promising data so far, no epigenetically active agents or drugs targeting histone acetylation and/or methylation have actually entered clinical trials for CVDs, nor have they been approved by the FDA. To ensure the most effective prevention and treatment possible, further studies are required to understand the complex relationship between epigenetic regulation and the development of CVD. Similarly, several classes of RNA therapeutics are currently under development. The use of miRNAs and their targets as diagnostic or prognostic markers for CVDs is promising, but has not yet been realized. Further studies are necessary to improve our understanding of the involvement of IncRNA in regulating gene expression changes underlying heart failure. Through the data obtained from such studies, specific therapeutic strategies to avoid heart failure based on interference with incRNA pathways could be developed.

Together, research and testing findings raise hope for enhancing the therapeutic armamentarium. This review presents the currently available data concerning epigenetic mechanisms and compounds involved in cardiovascular diseases, as well as preventive and therapeutic approaches against them.
\end{abstract}

Keywords: Cardiovascular disease, Epigenetics, Therapy, Prevention

\section{Background}

In the western world, cardiovascular disease is the most common cause of human morbidity and mortality. Expenses for the treatment of cardiovascular disease to the European health care system are presumed to be as high as 200 billion Euros each year [1].

In the USA, the overall rate of deaths attributed to cardiovascular disease (CVD) in 2011 was 229.6 per 100,000 Americans [2]. Thus, CVD still accounted for $31.3 \%$ (786 641) of all 2,515,458 deaths in the USA [2]. Based on the death rate data from 2011, more than 2150

Correspondence: susanne.voelter-mahlknecht@med.uni-tuebingen.de University Hospital of Tuebingen, Institute of Occupational and Social Medicine and Health Services Research, Wilhelmstr. 27, 72074 Tuebingen, Germany
Americans die of CVD each day, which equals an average of one death every $40 \mathrm{~s}$ [2]. The cardiovascular disease epidemic is rapidly spreading throughout the world. There are estimates that in 2030, nearly 23.6 million people will die from CVD worldwide [3, 4]. Due to an aging population and shifting risks posed by the environment, this burden is expected to increase in developing countries. In these countries, diets are changing to include higher sodium and fat content. The majority of the fatalities caused by CVD are, however, preventable $[5,6]$. According to epidemiological and clinical studies, lifestyle modifications to nutrition and exercise can be initial protective measures to reduce CVD risk $[7,8]$.

In addition, mortality rates are higher and prognoses are generally worse in patients with diabetes suffering a 
cardiovascular event [9]. As a consequence of better primary and secondary prevention, there is a decrease in cardiovascular events in type 1 and type 2 diabetic patients, as well as an increased life expectancy. Nevertheless, epidemic bursts of obesity in connection with decreased physical activity and increased survival in the general population have also led to a higher incidence of type 2 diabetes worldwide. This in turn contravenes the decrease in diabetes-related mortality that would otherwise increase significantly in the coming decades [9].

Despite the improvement of cardiovascular outcome and survival of heart failure patients through strategies of classical pharmacological treatment (e.g., the use of beta-blockers and angiotensin-converting enzyme (ACE) inhibitors), such therapies are ultimately unable to prevent further progression of the disease itself [10]. Thus, a more thorough understanding of underlying mechanisms, in the field of epigenetics, for instance, and the development of innovative and more effective therapies for heart diseases is necessary.

\section{Review}

Epigenetic alterations in gene expression may be achieved through changes in the tertiary structure of a DNA strand. Without altering the DNA sequence itself, epigenetic alterations in the form of chromatin-based modifications affect only the expression of the targeted genes [11]. Among these modifications are the methylation of DNA, the posttranslational modification of histone proteins, and RNA-based mechanisms [12]. The development of therapeutic strategies has been strongly encouraged by the reversible nature of such epigenetic alterations, as they allow direct targeting by various epigenetic components [11].

Preliminary research has shed light on the correlations between DNA methylation, histone modifications, and RNA-based mechanisms with CVD including atherosclerosis, heart failure, myocardial infarction, and cardiac hypertrophy. Currently, several therapeutic agents based on these mechanisms are being tested for their potential utility in clinical practice [13]. Although much data have been accumulated so far, no epigenetically active agents have entered clinical trials for CVD. Research on the potential use of epigenetically active compounds to treat these pathologies is, thus, only preliminary.

In the following, the currently available data concerning epigenetic mechanisms and compounds involved in cardiovascular diseases will be presented. The assignment of the discussed substances to different mechanisms of action is shown in Fig. 1. It has to be differentiated between

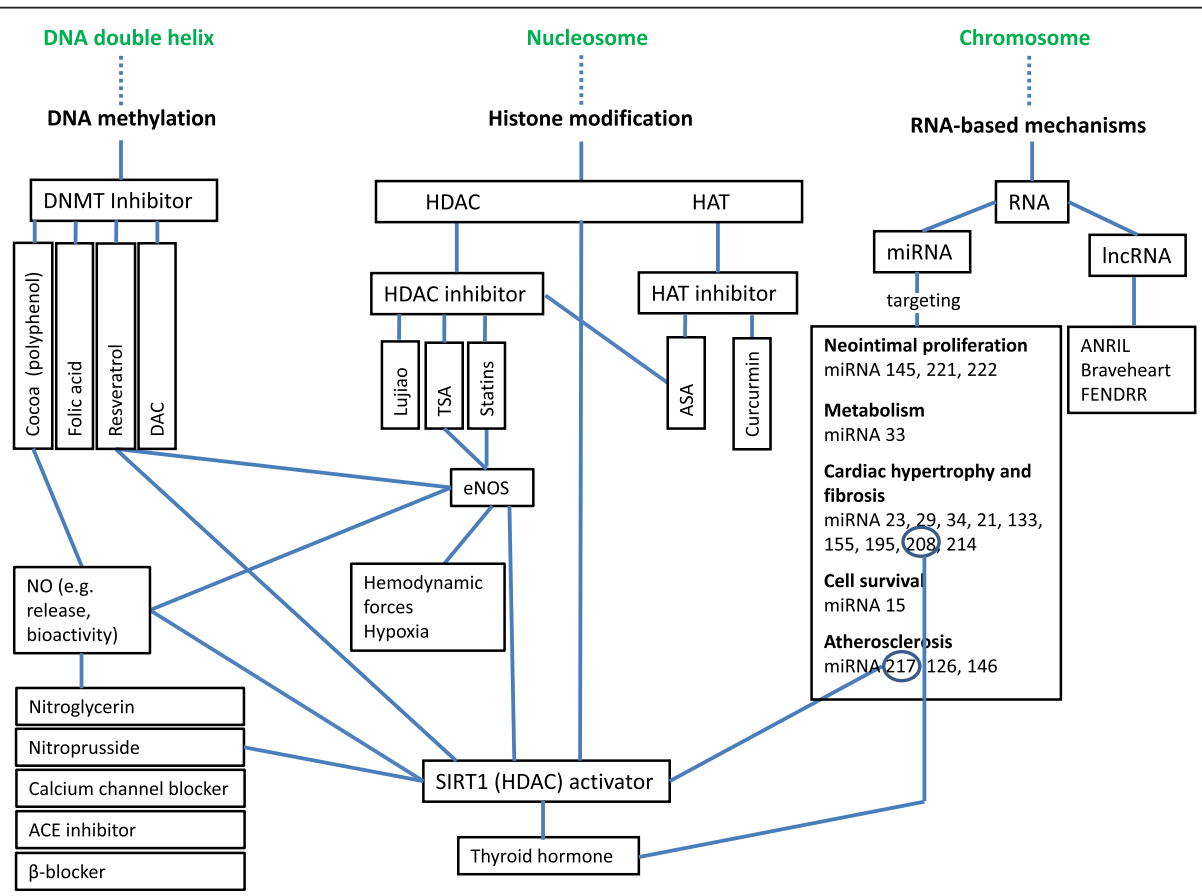

Fig. 1 Potential epigenetic mechanisms (DNA methylation, histone alteration, RNA-based mechanisms) and compounds involved in cardiovascular disease. ACE angiotensin-converting enzyme, ANRIL anti-sense non-coding RNA, ANRIL anti-sense non-coding RNA in the INK4 locus, ASA acetylsalicylic acid, ASOs anti-sense oligonucleotides, CHD coronary heart disease, CVD cardiovascular disease, DAC 5-aza-2-deoxycytidinedemethylating agent, DNMT DNA methyltransferase, eNOS endothelial nitric oxide synthase, FENDRR FOXF1 adjacent non-coding developmental regulatory RNA, HAT histone acetyltransferase, HDAC histone deacetylase, IncRNA long non-coding RNA, miRNA microRNA, NO nitric oxide 
the mechanisms of DNA methylation, histone modification, and RNA-based mechanisms.

\section{DNA methylation (Fig. 1)}

The methylation of DNA is regulated by DNA methyltransferases (DNMT1, DNMT3a, and DNMT3b) in the presence of S-adenosyl-methionine; this is the methyl donor for methylation of cytosine residues at the C-5 position to yield 5-methylcytosine $[14,15]$. DNA methylation states regulate biological processes underlying CVD, such as atherosclerosis, inflammation, hypertension, and diabetes [16-19].

One DNA methyltransferase (DNMT) inhibitor is 5aza-2-deoxycytidinedemethylating agent $(D A C)$, which induces the reexpression of hypermethylated silenced genes which might include the reexpression of hypermethylated estrogen receptor (ER) alpha and ER beta in normal smooth muscle and endothelial cells. The failure of estrogen therapy to exert cardioprotective effects might be explained by the silencing of ERs in women that result from epigenetic changes. Thus, CVD may be prevented successfully through the combined use of epigenetic and hormone replacement therapy [13].

Studies in humans have shown that certain dietary compounds can modulate the status of DNA methylation [13]. As one of the largest and most ubiquitous groups of phytochemicals, polyphenols are contained in fruits, vegetables, and other dietary components including green tea, red wine, and cocoa [20,21]. Various studies have indicated a connection between a polyphenol-rich diet and a reduced risk of CVD [13, 22-24]. Polyphenols are believed to be the principal anti-inflammatory mediators. Inflammation is a cardiovascular risk factor in and of itself, while all other cardiovascular risk factors can, in turn, be linked back to inflammation $[25,26]$.

One of the main sources of polyphenols in the human diet are cocoa products. The protective capacity of these cocoa polyphenols in connection with CVD inflammation has been the target of many human intervention studies [27].

Cocoa polyphenols possess a range of cardiovascular protective properties and can play a meaningful role by modulating different inflammatory markers involved in atherosclerosis [27]. Numerous population studies found a correlation between cocoa intake (e.g., chocolate) and reduced CVD risk [13], as well as an inverse association between cocoa intake (e.g., chocolate) and CVD mortality [22, 28-30]. In the study by Janszky [29], however, the occurrence of uncontrolled confounders could not be excluded. Furthermore, the patients were only asked about their general chocolate consumption without a differentiation between dark and milk chocolate.

Substantial evidence suggests that the consumption of cocoa has an effect on multiple cardiovascular risk factors, such as blood pressure [31], lipid profiles [32], and flow-mediated vascular dilatation [27, 33]. Nevertheless, analytical works like that by Jia and colleagues also have their limitations [32]. For one, the quality of the studies included in their meta-analysis varies significantly: Based on the standard for clinical trials of prescribed medicine, only three of the eight trials discussed were high-quality studies (Jadad score $\geq 4$ ), while the other five studies were of low quality. This suggests that more high-quality, large, randomized, and doubleblinded studies are necessary to secure data on this issue. Additionally, the effectiveness of long-term cocoa supplementation on the lipid profile could not be supported by any reports. While human and animal experiments show that the effect of cocoa is indeed dependent on pretreatment concentrations of cholesterol, to date, the effect of cocoa in dyslipidemia patients has not been tested in randomized trials. These studies only tested soft endpoints, meaning cholesterol changes from baseline and not clinical outcomes of the treatment.

The report by Hooper et al. [34], on the other hand, is the first systematic assessment of the effectiveness of the range of flavonoid subclasses and flavonoid-rich food sources on CVD risk factors based on randomized controlled trials [34]. Nevertheless, the review lacks quantifying approaches to the effects of flavonoid-rich food and extracts on CVD risk factors, as it does not include studies assessing their effects on CVD. In addition, it fails to provide sufficient well-designed studies of risk factors for most flavonoids. The small number and size of the included studies, as well as significant differences of the baseline levels of specific outcomes between intervention and control arms in parallel studies, the missing report of a paired $t$ test in crossover studies, and a variety of studies based on missing or poorly reported data present further weaknesses of the review. The methodological validity of the review is similarly problematic, mostly due to its lack of evidence concerning adequate allocation concealment, its blinding procedures, the similarity of intervention and control arms in terms of saturated fat intake and the predominance of industrially funded studies, as well as possible reporting bias. Altogether, this may lead to an exaggerated image of effectiveness [35]. Where Hooper et al. present evidence on the effectiveness of flavonoid-rich food, it is unclear whether the flavonoids themselves solely or partially cause the observable effects, or whether other bioactive components are responsible for the same [34].

Cocoa extract has been found to inhibit the expression levels of genes encoding DNMTs and methylenetetrahydrofolate reductase (MTHFR) in vitro [20]. Polymorphisms in the MTHFR gene have been found to be possible risk factors for a variety of common conditions, e.g., heart disease. 
Cocoa polyphenols decrease the susceptibility of low-density lipoprotein (LDL) to oxidation and inhibition of platelet activation and aggregation [36-40]. In addition, cocoa polyphenols affect the most significant markers of CVD: lipid profiles [36, 41], blood pressure [31, 42, 43], hemostasis [44-46], and endothelial dysfunction [47-49].

The study by Faridi et al. [49] is the first to examine how sugar-free cocoa acutely affects endothelial function and blood pressure, but it also has its limitations. For one, the findings apply to acute cocoa ingestion only. The measurements of endothelial function are limited to a single time point, which makes them prone to neglect temporal and maximal differences. In addition, since plasma catechin concentrations were not measured, it is unclear whether effects could be attributable to these components or not. Moreover it remains uncertain whether the observed effects were exclusively caused by the deliberate interventions, as the study lacked in dietary information and control of its subjects. The homogeneous population of the study, consisting mainly of white women concentrated around the Naugatuck Valley, finally allows only limited generalizations of its findings.

It is well known that alterations in plasma cholesterol levels (LDL-c and high-density lipoprotein (HDL-c)) are related to the progression of atherosclerosis and CVD [50]. Studies have shown dietary interventions with cocoa powder in mild hypercholesterolemic patients to significantly lower levels of LDL-c [51], while the level of HDL-c was increased in normo- and mild hypercholesterolemic patients after consuming dark chocolate or cocoa powder [37, 51, 52].

In addition, cocoa polyphenols have an effect on nitric oxide (NO) [27, 35, 47]. After consuming cocoa beverages which contained different contents of flavanols, healthy subjects exhibited an increase in their plasma nitric oxide.

Folic acid and B vitamins, other kinds of DNMT inhibitors, directly supply the one-carbon-metabolism with methionine for the production of S-adenosylmethionine [53]. A deficiency in folic acid leads to global DNA hypomethylation which correlates with an increased risk of cancer and cardiovascular diseases, such as atherosclerosis, coronary heart disease (CHD), and anemia [54-56].

Yang et al. [56] tried to avoid limitations of metaanalyses, like search comprehension and selection, the accuracy of study methodologies, and publication bias, by maximizing study identification and minimizing biases through an a priori development of the study protocol, a profound survey of several databases, and the definition and execution of explicit criteria for the selection of applicable studies, data collection, and data analysis. As a positive result, the results of the included trials did not exhibit any substantial heterogenities.
Vitamin B complex (folic acid and vitamins B6 and B12) substitution therapy leads to a decreased plasma homocysteine level [57]. Folic acids themselves are necessary to methylate homocysteine (Hcy) to methionine. Low serum levels of folic acid have furthermore been connected to increased serum levels of Hcy [13]. Hcy serum levels are increased through the common C677T variant in MTHFR. The risk of CVD increases 14-21\% in individuals with the homozygous TT genotype [58]. Daily dietary supplementation with folic acid and B vitamins reduces plasma Hcy levels, which in turn decreases the risk of CVD in healthy subjects or improves the likeliness of survival in patients with CHD [59]. This is, nevertheless, a controversial effect, as the reducing Hcy concentrations has not proven to be beneficial in the majority of clinical studies. Although folic acid supplementation shows a potentially modest benefit in stroke prevention, it does not seem to exhibit benefits in connection with preventing CHD and CVD [56, 60]. On the contrary, a meta-analysis indicated a potential detrimental effect of folic acid in subjects with high baseline Hcy $[60,61]$. However, the study by Miller et al. [60] is limited by (i) differences in the composite clinical end points between trials and in CVD risk factors for trial participant-based eligibility criteria; (ii) an inconsistent and incomplete discussion of baseline homocysteine level results that preclude a more detailed assessment of interactions; and (iii) neglecting that subgroup effects and potential interactions may occur solely by chance.

Homocysteine is a serious, independent risk factor for atherosclerosis [57]. Vascular complications and an increased cardiovascular risk in connection with increased circulation levels of homocysteine may, as various studies indicate, be caused by the methylation of DNA [62] It is assumed that lowering plasma homocysteine levels will result in a decreased risk of CVD [13].

Nevertheless, recent large randomized studies (VISP, NORVIT, and HOPE-2) [63, 64] could not conclude that this is actually the case. These studies, particularly "NORVIT" and "VISP," have specific deficiencies: The "NORVIT" study did not include vitamin deficiency and increased homocysteine levels as inclusive criteria. Although a preventive effective of vitamins can only be expected after 3 years [65], this study also considered secondary findings that were observed immediately after a cardiac event. Folic acid levels in the placebo group of this study, for instance, rose from an initial 9.6 to $13.1 \mathrm{nmol} / \mathrm{l}$, similar to the verum group. This suggests that over time, the placebo group may have become nonexistent. Furthermore, Walk et al. suggest that a statistically sound evaluation of the effects of decreasing homocysteine levels through secondary prevention would have required the observation of ca. 20,000 patients over a period of 5 years [65]. The "VISP" study, on 
the other hand, only used high-dose and a low-dose vitamin groups, but no placebo group [66]. Incidentally, in 1998, the USA and Canada passed a law on the enrichment of wheat products with folic acid, which would have falsified and thus annihilated the further examination of folic acid deficiencies in test subjects [66]. Moreover, Rajan et al. concluded from a study published in 2002 [67] that their high-dose group was still not receiving enough vitamin B12 to compensate an insufficient gastrointestinal resorption of the vitamin, which led to a further blurring of the results between the lowdose and high-dose groups.

The polyphenol resveratrol (RESV) is a DNMT inhibitor found in various plants, including grapes, berries and peanuts [68], and in processed foods such as red wine [69]. It modulates the expression of several targets, such as sirtuin 1, p38 mitogen-activated protein kinase (MAP38 kinase), nuclear factor "kappa-light-chain-enhancer" of activated $B$ cells (NF-kB), activating protein-1 (AP-1), endothelial nitric oxide synthase (eNOS), as well as inflammatory cytokines, like tumor necrosis factor alpha and interleukin- 6 and interleukin-8, as well as vascular cell adhesion molecule-1 (VCAM-1) and intercellular adhesion molecule-1 (ICAM-1) [13, 70]. Metabolic disorders, chronic heart disease, and inflammatory diseases can be improved by resveratrol through its upregulation of SIRT1 in endothelial cells [70]. Resveratrol also possesses a number of bioactivities, such as antioxidant, anti-inflammatory, and cardioprotective effects [69].

In vitro, RESV has exhibited the ability to enhance the activity and expression of eNOS [68]. It was also found to prevent an increase in vasoconstrictors, like angiotensin II and endothelin-1, as well as intracellular calcium, in mesangial cells [69]. Antioxidative effects of resveratrol on low-density lipoproteins (LDL) were identified by Frankel et al. in 1993 [71].

In conclusion, unaltered epigenetic regulation pathways like DNA methylation and posttranslational chromatin modifications constitute the basis of a healthy cardiovascular system. To date, many studies have shown the possibilities and positive effects of treatment with epigenetic modulators.

\section{Histone modification (Fig. 1)}

\section{Histone acetyltransferase (HAT) modification}

The HAT inhibitor curcumin (diferuloylmethane) is a polyphenol present in a curry spice exhibiting a diverse range of molecular targets, such as growth factors and their receptors, transcription factors, enzymes, cytokines, and genes regulating cell proliferation and apoptosis [13].
Curcurmin modulates epigenetic factors [72] and has effects on the regulation of histone deacetylases, histone acetyltransferases, DNA methyltransferase I, and miRNAs [72]: Out of the various studies that have been conducted on the effects of curcumin on histone deacetylase (HDAC) expression, Bora-Tatar et al. [73] found that from among 33 carboxylic acid derivatives, curcumin proved the most effective HDAC inhibitor and, as such, even more potent than the well-known HDAC8 inhibitors valproic acid and sodium butyrate. HDAC 1,3 , and 8 protein levels can be significantly decreased by curcumin [73-76].

To the contrary, HDAC2 was activated, restored, and increased in its protein expression by curcumin [77, 78].

Obviously, the different effects of curcumin on the various subtypes of HDAC enzymes indicate the necessity of further research to secure an understanding of the exact relationship between curcumin and HDAC expression [72].

Curcumin is furthermore a potent HAT inhibitor. It inhibits p300 [79-86], inhibits GCN5 associated with hypoacetylation of histone $\mathrm{H} 3$ [87], and inhibits GCN5 associated with hypoacetylation of histone $\mathrm{H} 3$ [87].

The fact that curcumin modulates both HDAC and HAT suggests a common underlying mechanism. Oxidative stress can, for instance, activate NF- $\mathrm{kB}$ through the stimulation of intrinsic HAT activity, which results in the expression of pro-inflammatory mediators, but it can also inhibit HDAC activity [88]. Curcumin as an antioxidant may similarly influence both acetylation and deacetylation by regulating oxidative stress [72].

Nevertheless, only a few studies have investigated the effect of curcumin on the methylation of DNA [72]. For one, it seems to covalently block the catalytic thiolate of DNMT1 in order to exert its inhibitory effect on DNA methylation [89]. This previous understanding was however thwarted by a more recent study that showed no curcumin-dependent demethylation, which in turn suggests that curcumin has little or no pharmacological relevance as a DNMT inhibitor [90]. These contradictions and other inconsistencies about the influence of curcumin on DNMT point to the urgency of further research in this area [72]. Additionally, curcurmin is known to covalently block the catalytic thiolate of C1226 of DNA methyltransferase I [89] and to induce global genomic DNA hypomethylation [89].

Further, Sun et al. [91] found that curcumin altered miRNA expression in human pancreatic cancer cells, in which miRNA-186 and miRNA-199a were the most downregulated and miRNA-22 was the most upregulated [72, 92]. This curcumin-induced upregulation simultaneously suppressed the expression of its target genes $\mathrm{Sp} 1$ and estrogen receptor 1 [91].

Curcumin also downregulates the activation of nuclear factor kappa-light-chain-enhancer of activated B 
cells (NF- $\mathrm{kB}$ ) by various tumor promoters, including phorbol ester, tumor necrosis factor, and hydrogen peroxide [93, 94]. Curcumin-induced downregulation of NF- $\mathrm{kB}$ is mediated through the suppression of the activation of IкB $\alpha$ kinase (IKK) [93].

Protective effects of curcurmin on the cardiovascular system have been demonstrated [95]. In fact, the administration of curcumin to healthy volunteers and patients with atherosclerosis has proven to significantly lower LDL levels and increase HDL levels $[96,97]$. Both a rat model of heart failure and primary cultured rat cardiac myocytes and fibroblasts have shown curcumin to prevent ventricular hypertrophy and to perpetuate systolic function [98]. In rat cardiomyocytes, curcumin seems to act through two or more mechanisms at once: through the inhibition of histone acetylation and hypertrophyresponsive transcription factors, including GATA binding protein 4 (GATA4), as well as through the disruption of p300/GATA4 complex [99].

In human subjects, studies indicated that acetylsalicylic acid (ASA) therapy reduces ABCA1 DNA methylation levels that are independent from aging and CHD status of patients, which suggests that this molecular mechanism is involved in the pathophysiology of $\mathrm{CHD}$ and thus points towards new therapeutic strategies [100].

\section{HDAC modification}

The sirtuin 1 protein (SIRT1) is a member of the class III NAD+-dependent histone deacetylases. These sirtuins, and particularly SIRT1, participate in the response to DNA damage, metabolism, longevity, and carcinogenesis. Furthermore, different cellular processes, such as differentiation, proliferation, and apoptosis through deacetylation of important regulatory proteins such as p53, FOXO3a, and NF-kB, are regulated by SIRT1.

The activity and expression of human SIRT1 can be activated or inhibited by various modifiers, including food and cosmetic additives. Agents such as L-thyroxin and sodium nitroprusside frequently used in clinical practice were identified to be potent activators of human SIRT1 expression [101]. The exposure of euchromatin-associated epigenetic marks to T3 induces SIRT1 by enhancing histone acetylation and RNAP II recruitment [102].

Furthermore, the treatment of peripheral blood mononuclear cells (PBMCs) with sodium nitroprusside has been associated with a high increase in cellular lifespan, while L-thyroxin was unable to prolong lifespan, which suggests that an isolated upregulation of SIRT1 is insufficient to promote longevity [101]. Perhaps these agents can be used in everyday clinical practice for indications with a tolerable number of side effects [103-106].
Thyroid hormones can contribute to cardiac repair and regeneration through the reactivation of developmental gene programming [107] and can have important effects on heart remodeling through mir-208 [108]. Thyroid hormones have been identified as independent determinants of functional recovery and mortality after myocardial infarction [107]. Concerning the potential for therapeutic measures, thyroid hormones as an agent contributing to the regeneration or repair of the ischemic myocardium are awaiting testing in clinical trials [109].

Sodium nitroprusside is a medical agent that belongs to the class of cyanides. It is highly efficient in decreasing blood pressure and exerts vasodilating activity through release of nitric oxide $(N O)$ in smooth muscle cells and the vessel wall. NO is thus a vasodilator that mediates multiple physiological and pathophysiological activities in the cardiovascular system and protects against the development of atherosclerosis [13].

The signaling molecule nitric oxide is produced in endothelial cells by eNOS [110]. eNOS, which is encoded by the gene NOS3, catalyzes the generation of NO from L-arginine in blood vessels [111]. NOS3 is the best-characterized endothelial gene in association with cardiovascular physiology [13]. Endothelial dysfunction is primarily characterized by a reduction in eNOS expression and the bioavailability of NO [112]. This reduction, which takes place in the neointimal coverings of advanced atheromatous plaques, is a prominent feature of endothelial dysfunction [113-116].

A variety of risk factors contributes to dysfunction of endothelial cells through changes in eNOS expression and activity [113-116]: Both transcriptional and posttranscriptional mechanisms controlling eNOS mRNA levels have been associated with the same [117-120]. The differential expression of eNOS is, furthermore, caused by such hemodynamic forces at characteristic regions within the vasculature as arterial curvatures and bifurcations [113].

Additionally, hypoxia is known to significantly downregulate NOS gene expression in endothelial cells $[13,121]$ in association with a post-transcriptional downregulation of eNOS mRNA expression [122, 123]. Posttranscriptional regulation of eNOS mRNA stability is an important component of eNOS regulation, especially under hypoxic conditions [110].

The expression of eNOS is induced and directly upregulated by SIRT1 [124]. SIRT1 may also be related to the inhibition of oxidized low-density lipoprotein (oxLDL)-induced apoptosis and the improvement of endothelial relaxation [124]. Due to these mechanisms, SIRT1 is considered an anti-atherosclerotic factor [124]. The activation of SIRT1 is thus an important innovative therapeutic target in future treatment strategies of cardiovascular disease $[125,126]$. 
NO insufficiency-e.g., in atherosclerosis, hypertension, arterial thrombotic disorders, heart failure, coronary heart disease, and stroke [11, 17, 127-134] - may reflect an absolute deficit of $\mathrm{NO}$ (synthesis), impaired availability of bioactive $\mathrm{NO}$, or enhanced $\mathrm{NO}$ inactivation. A broad spectrum of pharmacotherapeutics in cardiovascular medicine works on either the replacement or augmentation of endogenous NO through exogenously administered NO donors.

For decades, clinical practice has used several $N O$ donors (e.g., nitroglycerin and nitroprusside), for instance to treat hypertension and heart failure [135]. Due to their therapeutic half-life, systemic absorption with potentially adverse hemodynamic effects, and drug tolerance, conventional nitrate compounds are limited in their treatment applications [17, 127]. Novel NO donors offering selective effects, a prolonged half-life, and a diminished incidence of drug tolerance have been developed to overcome these limitations.

Calcium channel blockers, e.g., dihydropyridine calcium channel antagonists, have been a common treatment of angina pectoris and hypertension for years [136]. They act through inhibiting the smooth muscle Ltype calcium current, which decreases the intracellular calcium concentration and induces smooth muscle relaxation. Dihydropyridine can, furthermore, initiate the release of NO from the vascular endothelium [136].

Angiotensin-converting enzyme (ACE) inhibitors are cardiovascular agents that modulate endogenous NO bioactivity. ACE degrades bradykinin [137] and generates angiotensin II; bradykinin, in turn, has exhibited the ability to stimulate the endothelium to release vasodilating substances, in particular NO. By increasing bradykinin, ACE inhibitors may thus enhance the release of endothelial NO. It has been shown that ACE inhibitors exert some of their beneficial pharmacological effects by increasing vascular NO activity [138-140].

$\beta$-blockers may also obstruct the NO pathway [135]. Nebivolol, a $\beta_{1}$-blocker and chemical racemate containing equal proportions of D- and L-enantiomers [141], for instance, reportedly induces endothelium-dependent arterial relaxation in dogs in a dose-dependent manner [142]. The endothelium-dependent relaxation caused by nebivolol is abolished by $N$-nitro-L-arginine methyl ester, an inhibitor of NO synthase [135].

Dysfunction of histone acetylation has been associated with the pathogenesis of chronic heart failure. Lujiao, an agent that is long known in traditional Chinese medicine, has previously been used in the treatment of heart failure [143]. This medicine has been considered a potential therapy for hypertrophic cardiomyocytes on histone acetylation [143].

Histone deacetylase (HDAC) "inhibitors attenuate pathological cardiac remodeling and hypertrophic gene expression; yet, the direct histone targets remain poorly characterized" [144]. There are studies suggesting "a mechanism for cardioprotection subject to histone deacetylation as a previously unknown target, implicating the importance of inflammation by pharmacological HDAC inhibition" [144].

HDAC inhibitor trichostatin A (TSA) is an anti-fungal antibiotic agent that is being produced by Streptomyces platensis that selectively blocks class I and class II HDACs in mammals, but not class III HDACs [145]. TSA is known to be an epigenetic modulator [146] and HDAC inhibitor [146]. Although TSA decreases both eNOS protein and mRNA levels, TSA paradoxically enhances the activity of the eNOS promoter and does not alter the eNOS transcription rate in nuclear run-on experiments. This suggests that TSA post-transcriptionally targets eNOS mRNA. eNOS expression in ECs seems to be regulated partly by HDAC-dependent mechanisms [147]. Furthermore, trichostatin A treatment increases the expression of (encoding estrogen receptors) ERa and $\mathrm{ERb}$ in endothelial cells [13]. Encoding estrogen receptors ERa and ERb (ESR1 and ESR2, respectively), atheroprotective genes are consistently hypermethylated in human coronary atherosclerotic tissues and plaque regions of the ascending aorta [13]. Both smooth muscle cells and endothelial cells exhibit ERs in the coronary arterial wall which may protect against atherosclerosis, especially in CHD. Deficiencies in ERa have proven to accelerate atherosclerosis in human subjects [133]. The risk of cardiovascular diseases can be reduced about 30 to $50 \%$ by estrogen substitution [148].

In vivo studies in animals have shown treatment with trichostatin A to improve functional myocardial recovery after myocardial infarction. Treatment of myocardial infarction with trichostatin $\mathrm{A}$ has proven to increase angiogenesis [13]. It can hence be concluded that HDAC inhibition may lead to the preservation of cardiac performance and mitigate myocardial remodeling through the stimulation of endogenous cardiac regeneration [149]. HDAC inhibition has furthermore been shown to enhance the formation of myocytes and microvessels in the heart. Due to its ability to stimulate angiogenesis, HDAC inhibition is capable of minimizing the loss of myocardial performance following myocardial infarction [13].

Statins are used as primary and secondary prophylaxis against atherosclerosis and cardiovascular incidents [150]. They also act as a first-line treatment to decrease serum cholesterol levels in patients with high cholesterol [13] (e.g., polygenetic hypercholesterolemia or familial hypercholesterolemia but also combined hyperlipidemia) by inhibiting 3-hydroxy-3-methylglutaryl coenzyme A (HMG CoA) reductase [135].

In addition, statins have many pleiotropic effects. Among these are beneficial effects on endothelial function 
and blood flow, decreased LDL oxidation, enhanced atherosclerotic plaque stability and decreased proliferation of vascular smooth muscle cells and platelet aggregation, as well as reduced vascular and atherosclerotic inflammation, which is caused by histone modifications and an inhibited release of pro-inflammatory cytokines [13].

They may furthermore possess antioxidant properties [151] and be able to upregulate eNOS activity and expression (via the inhibition of Rho) [135]. Through the induction of hypoxia and oxidized LDL, statins reverse the downregulation of eNOS expression [152], which may ultimately be the reason for their ability to improve the vascular bioactivity of NO [153] and atherosclerotic plaque stability $[17,154]$. These various effects are likely to be highly significant in the setting of chronic statin therapy as a primary and secondary prevention measure of coronary heart disease [135].

Although statins are usually well-tolerated, side effects such as myopathy occur in approximately $10 \%$ of patients receiving treatment [155] and a number of patients are statin resistant (estimates of up to $20 \%$ ) or intolerant. Thus, new therapies are necessary to reduce the residual disease burden in these patient populations [156].

\section{RNA-based mechanisms (Fig. 1)}

\section{1. miRNA therapeutics}

MicroRNAs (miRNA or miR) are short (20-22 nucleotides) non-coding RNAs [157] modulating gene expression further by downregulating the translation of target mRNAs through the inhibition of post-transcriptional events, through transcript degradation or through direct translational suppression [13, 156]. Estimates based on computational approaches currently find more than $60 \%$ of human genes to be targeted by miRNAs, with many of these interactions being highly conserved throughout evolution [158].

In mammals, more than 1000 different miRNAs have been described. Among these are cardiac miRNAs, which, as studies indicate, can potentially be modulated by oligonucleotide-based therapies (Table 1) $[10,13,107$, 156, 159-181].

miRNAs may possibly be used as diagnostic biomarkers of, e.g., heart disease [182], as they have been found in the serum and plasma of humans and animals and are highly significant in the pathogenesis of cardiovascular diseases. miRNAs qualifying as biomarkers are circulating miRNA-126 and miRNA-145, which are reduced in the serum of patients with coronary artery disease [183], and miRNA-1, miRNA-133b, and miRNA499, which are elevated in patient and animal models during acute myocardial infarction $[184,185]$.
Biological gene networks may be altered by a dysregulation of miRNAs in disease states. miRNA replacement therapy or anti-sense inhibition of miRNAs may aid in restoring gene expression in the cell to its normal state. In the same way, gene networks, such as those controlling key cellular processes like cholesterol efflux, can be targeted by miRNAs, making their characteristic modulation of entire gene pathways instead of single targets a new approach for the treatment of disease [156]. The ability to target single miRNAs and to alter the expression of gene networks provides an exceptional approach to drug development that moves beyond the "one-drugone-target" mode of treatment.

miRNA therapeutics bear great potential for developing new CVD treatments. Preclinical studies already prove this through early successes with miRNA inhibitors and mimics [156]. As such, a number of RNA-based therapeutics are currently being developed by biotechnological companies. Among these innovations are miRNA (microRNA) sponges, miRNA mimetics, anti-miR oligonucleotides, and anti-sense oligonucleotides (ASOs) [156].

miRNA sponges are molecules developed to inhibit intra cellular miRNAs [186] and thus act as competitive inhibitors of the respective miRNA. The sponge binds to the miRNA of interest to prevent the latter from binding to its targets. Difficulties in determining the appropriate dosage may prove to be a disadvantage of this approach. A highly expressed miRNA, for instance, may require a potentially unfeasible dose of sponge to be silenced, whereas an abundance of miRNA target genes would need a much lower dose of sponge to silence the miRNA [156].

miRNA mimetics are small, chemically modified doublestranded RNAs mimicking the function of an endogenous miRNA. They are delivered as perfect complementary duplexes to improve RNA-induced silencing complex (RISC) loading of miRNA [187]. Their efficiency can furthermore be enhanced by increasing the affinity for a specific target and reducing other unwanted miRNA effects [188].

Anti-miR oligonucleotides, chemically modified to enhance target affinity, stability, and tissue uptake, are a promising approach [189]. Preclinical studies in mice and non-human primates have shown that these compounds rapidly leave the plasma upon systemic delivery. After entering these cells, the anti-miR forms a stable, high-affinity bond with the miRNA, which reduces the availability of the same to bind with the 3'UTR of the miRNA target [156]. Chemically modified anti-miRs have proven to be therapeutically beneficial in mouse models of cardiac dysfunction [156].

ASOs are single stranded, short, synthetic 14-22 nt highly specific, complementary oligonucleotides that localize to the nucleus and target a single gene through the interruption of mRNA translation. This in turn is 
Table 1 Mechanisms, clinical relevance, targets and development of microRNA-based therapeutics by companies

\begin{tabular}{|c|c|c|c|c|}
\hline & Mechanisms and clinical relevance & Target(s) & $\begin{array}{l}\text { Development of microRNA-based } \\
\text { therapeutics by companies }\end{array}$ & References \\
\hline miR-208 & $\begin{array}{l}\text { 1. Inhibition of miR-208a prevents cardiac remodeling } \\
\text { 2. Role in cardiac fibrosis not yet fully identified }\end{array}$ & $\mathrm{p} 21$ & $x$ & {$[10,107]$} \\
\hline miR-33 & $\begin{array}{l}\text { 1. Targets genes involved in HDL metabolism. Preclinical } \\
\text { models in which anti-miR-33 was delivered for up to } 12 \\
\text { weeks have shown no adverse effects of the approach } \\
\text { (assessed by liver enzymes, plasma cytokine levels, blood } \\
\text { chemistry panels, blood counts, body weight) } \\
\text { 2. Directly target macrophages and cause a regression } \\
\text { of atherosclerosis }\end{array}$ & $\begin{array}{l}\text { ABCA1, ABCG1, AMPK alpha, CPT1A, CROT, } \\
\text { HADHB, IRS2, NPC1, PRKAA1, SREBP-1 }\end{array}$ & $\begin{array}{l}\text { Anti-miR oligonucleotide against } \\
\text { miR-33a/b for treating atherosclerosis } \\
\text { and dyslipidemia }\end{array}$ & {$[156,160,179]$} \\
\hline $\operatorname{miR}-146$ & Pathogenesis and clinical manifestation of atherosclerosis & CD40L, IRAK1, IRAK2, TLR4, TRAF6 & & {$[180,181]$} \\
\hline $\begin{array}{l}\text { miR-15 family (including } \\
\text { miR-15, miR-16, miR-497) }\end{array}$ & $\begin{array}{l}\text { Associated with cell cycle arrest and survival by } \\
\text { regulating anti-apoptotic and cell cycle genes }\end{array}$ & CARM1 & $\begin{array}{l}\text { Anti-miR towards miR-15 for post- } \\
\text { myocardial infarction remodeling of } \\
\text { the heart. An 8-mer (nucleotide) } \\
\text { directed against the seed region of } \\
\text { the miR-15 family: more effective in the } \\
\text { derepression of target genes than the } \\
\text { previously used LNA-modified 16-mer }\end{array}$ & {$[161,162]$} \\
\hline \multirow[t]{3}{*}{$\begin{array}{l}\text { miR-23a, miR-23b, miR-24, } \\
\text { miR-195, miR-214 }\end{array}$} & $\begin{array}{l}\text { Overexpression of these microRNAs causes hypertrophy } \\
\text { in human cardiomyocytes }\end{array}$ & \multirow[t]{3}{*}{ CDC42 (miR195) } & \multirow{3}{*}{$\begin{array}{l}\text { anti-miR towards miR-195 for post- } \\
\text { myocardial infarction remodeling of } \\
\text { the heart. }\end{array}$} & \multirow[t]{3}{*}[161-163]{} \\
\hline & $\begin{array}{l}\text { Overexpression of miR-195 in the heart is a sufficient } \\
\text { cause for heart failure }\end{array}$ & & & \\
\hline & $\begin{array}{l}\text { Transgenic miR-195 mice may develop dilated } \\
\text { cardiomyopathy }\end{array}$ & & & \\
\hline miR-133 & Overexpression of miR-133 inhibits cardiac hypertrophy & SP1 & & {$[163,164]$} \\
\hline miR-34 & $\begin{array}{l}\text { The response of the heart to stress, including myocardial } \\
\text { infarction, leads to an upregulation of miR-34. Involved } \\
\text { in cardiac hypertrophy and fibrosis }\end{array}$ & SIRT1 & $\begin{array}{l}\text { LNA-modified anti-miR against } \\
\text { miR-34a aimed at improving systolic } \\
\text { pressure and increasing angiogenesis }\end{array}$ & {$[165]$} \\
\hline \multirow[t]{2}{*}{ miR-29 } & \multirow{2}{*}{$\begin{array}{l}\text { miR-29 is implicated in cardiac fibrosis and is } \\
\text { downregulated after myocardial infarct and after } \\
\text { cardiac injury }\end{array}$} & LPL (miR-29a) & \multirow{2}{*}{$\begin{array}{l}\text { Development of a pro-miR to target } \\
\text { multiple components of the fibrosis } \\
\text { pathway }\end{array}$} & \multirow[t]{2}{*}[166]{} \\
\hline & & DNMT3B (miR-29b) & & \\
\hline \multirow[t]{3}{*}{ miR-21 } & \multirow{3}{*}{$\begin{array}{l}\text { miR-21 levels in cardiac fibroblasts lead to a decrease in } \\
\text { its target mRNA, sprouty-1 (Spry1), a negative regulator } \\
\text { of ERK-MAP kinase activity, as well as fibroblast growth } \\
\text { factor-2 (FGF2) secretion }\end{array}$} & $\mathrm{BCL}-2, \mathrm{PDCD} 4$ & \multirow{2}{*}{$\begin{array}{l}\text { ASO to miR-21 in order to elevate } \\
\text { Spry1 expression, to reduce FGF2, and } \\
\text { therefore to decrease fibroblast growth }\end{array}$} & \multirow[t]{3}{*}{ [167-169] } \\
\hline & & PPARalpha, & & \\
\hline & & PTEN, TPM1, TLR4 & $\begin{array}{l}\text { Anti-miR-21 may help treat a variety of } \\
\text { fibrotic conditions, including cardiac } \\
\text { fibrosis }\end{array}$ & \\
\hline miR-155 & $\begin{array}{l}\text { miR-155 has been implicated in viral myocarditis. An } \\
\text { LNA-anti-miR directed against murine miR-155 reduced }\end{array}$ & $\begin{array}{l}\text { AT1R, ETS-1, MLCK, BCL-2, ETS-1, FADD, } \\
\text { HBP1, MAP3K10 }\end{array}$ & $x$ & {$[13,170-173]$} \\
\hline
\end{tabular}
HBP1, MAP3K10 
Table 1 Mechanisms, clinical relevance, targets and development of microRNA-based therapeutics by companies (Continued)

miR-145

1 Mechanisms, clinical

miR-221, miR-222

miR-126

miR-217

miR-1
Genetic deletion of miR-145 results in excessive

remodeling of the right ventricle and decreasing blood

pressure. After vascular injury, the cytoskeleton of

smooth muscle cells is modulated by a downregulation

$$
\text { of miRNA-145 }
$$

Proliferation of smooth muscle cells is partially enhanced by an increase in endogenous miRNA-221 and miRNA-222 levels

As atherosclerosis develops, the inflammation of vessel walls is enforced by a downregulation of miRNA-126 promoting the expression of VCAM-1 (vascular cell adhesion molecule) and inducing the production of CXCL12 (C-X-C motif chemokine 12), which in turn leads to the recruitment and adhesion of further inflammatory cells

When expression of miRNA-217 in atherosclerotic plaques increases, the endothelium disintegrates, which then leads to the inhibition of SIRT1 that causes an acceleration of vascular senescence

In developing mouse hearts, the overexpression of miR-1 causes decreased cardiomyocyte proliferation and premature differentiation. Experiments with mice suggest that transient downregulation of miR-1 may prove to be of therapeutic benefit to patients suffering from acute myocardial infarction

miR-1 negatively regulates key components of calcium signaling pathways and fetal gene activation, making it a vital part of agonist-induced cardiomyocyte

hypertrophy in the mouse
c-Kit, eNOS, ETS-1, PAK1, p27, p57, STAT5A

$\mathrm{BCL}-2, \mathrm{FOXO}$, IRS1

MLCK, KLF4, MRTF-A, PIM-1

$[13,177,178]$

ABCA1 ATP binding cassette transporter A1, ABCG1 ATP binding cassette transporter G1, AMPKa AMP kinase subunit-a, AT1R angiotensin II type 1 receptor, BCL-2 B-cell lymphoma 2, CARM1 coactivator-associated arginine methyltransferase $1, C D C 42$ cell division control protein 42 , CPT1A carnitine palmitoyltransferase 1A, CROT carnitine O-octaniltransferase, DNMT3b DNA methyltransferase $3 \mathrm{~b}$, eNOS endothelial nitric oxide synthase, ETS-1 E26 transformation-specific sequence 1, FADD Fas-associated death domain-containing protein, FOXO3 forkhead box O3, HADHB hydroxyacyl-CoA-dehydrogenase, IRAK1 interleukin-1 receptor-

associated kinase 1, IRAK2 interleukin-1 receptor-associated kinase 2, IRS1 insulin receptor substrate 1, IRS2 insulin receptor substrate 2, HBP1 HMG box-transcription protein 1, JAM-A junctional adhesion molecule-A, ass Liated kinase 1 , IRA M interleukin-1 receptor-associated kinase 2, IRS insulin receptor substrate 1, IRS2 insulin receptor substrate 2, HBPI HMG box-transcription protein 1, JAM-A junctional adhesion molecule-A,
LPL Lipoproteinlipase, MAP3K10 mitogen-activated kinase kinase kinase 10, MLCK myosin light chain kinase, MRTF-A myocardin-related transcription factor A, MYL9 myosin light chain 9, NOX4 NADPH oxidase 4, NPC1 LPL Lipoproteinlipase, MAP3K10 mitogen-activated kinase kinase kinase 10, MLCK myosin light chain kinase, MRTF-A myocardin-related transcription factor A, MYL9 myosin light chain 9, NOX4 NADPH oxidase 4, NPC
Niemann-Pick C1, PAK1 p21/Cdc42/Rac1-activated kinase 1, PDCD4 programmed cell death 4, PPARa peroxisome proliferator-activated receptor-a, PRKAA1 protein kinase, AMP-activated, a 1 catalytic subunit, PTEN phosphatase and tensin homologue, SIRT1 sirtuin 1, SirT1 silent information regulator 1, SREBP-1 sterol regulatory element-binding protein 1, STATSA signal transducer and activator of transcription 5A, TLR4 toll-like receptor 4, TPM1 tropomyosin 1, TRAF6 TNF receptor-associated factor 6 
achieved by an RNase $\mathrm{H}$ cleavage mechanism that degrades the transcript [190]. Thus, the target mRNA cannot be translated and the level of protein is reduced as it is prevented from reaching the ribosome [191, 192].

Mipomersen, a first-in-class ASO inhibitor recently approved by the FDA, inhibits a synthesis of messenger RNA (mRNA) of apolipoprotein B (Apo B) in the liver. Kynamro furthermore reduces LDL-c for the treatment of homozygous familial hypercholesterolemia. These findings enable other oligonucleotide-based therapies and thus bring miRNA therapeutics closer to clinical practice [193].

Another LDL-c lipid-lowering agent is lomitapide. Lomitapide and mipomersen both lower LDL-c through the reduced production of hepatic VLDL, which allows them to act independently of an LDL receptor, making them suitable treatment options for patients with homozygous familial hypercholesterolemia.

However, hepatic fat accumulation is intrinsincally linked to the processes connected to lomitapide and mipomersen. The long-term implications of this negative effect are unknown at this time [193]. Lomitapide can also cause gastrointestinal side effects, like diarrhea and nausea, which are, however, manageable by decreasing the medication dose and maintaining a strict low-fat diet. Lomitapide as a cytochrome P450 3A4 inhibitor has potential for drug-drug interactions with other cytochrome P450 3A4 inhibitors and drugs metabolized by cytochrome P450 3A4 [193]. Mipomersen, on the other hand, can lead to injection-site reactions and flu-like symptoms [193].

Kynamro currently has approval for treatment of familial hypercholesterolemia [194-196], a genetic disorder of lipid metabolism characterized by elevated LDL-c, as well as an increased risk of suffering premature coronary heart disease [156].

\section{Long non-coding RNAs (lncRNAs)}

While research predominantly discusses small noncoding RNAs, such as microRNAs, long non-coding RNAs (lncRNAs) are gaining more prominence as regulators of gene expression. The central role that lncRNAs play in heart development is only slowly being recognized. In addition, understanding the function of these molecules in CVD is even further away [13].

Long non-coding RNAs are a large and diverse class of transcribed RNA molecules, exhibiting a length of more than 200 nucleotides that do not encode proteins and are primarily located in the nucleus [197]. Long noncoding RNAs function either by binding to DNA or RNA in a sequence-specific manner or by binding to proteins [197]. They are transcribed as overlapping sense and anti-sense transcripts of coding DNA regions responsible for the regulation of the transcription of corresponding overlapping mRNA [198]. LncRNAs are functionally distinct from small non-coding RNAs, namely miRNAs, as the latter primarily mediate posttranscriptional repression in the cytoplasm. Certain lncRNAs are precursors for smaller regulatory RNAs such as miRNAs or piRNAs [197]. IncRNAs play a significant role in epigenetic regulation as they, for instance, mediate the activation or repression of target genes through methylation of DNA posttranslational histone modifications $[13,199]$. Their expression is developmentally regulated and can be tissue- and cell-type specific [197]. As lncRNAs are believed to bear important regulatory functions, they add yet another layer of complexity to our understanding of genomic regulation [197].

The lncRNA anti-sense non-coding RNA in the INK4 locus (ANRIL) [200-209] modulates atherosclerosis susceptibility at Chr9p21.3 and is overexpressed in human atherosclerotic plaques [201, 210]. ANRIL is furthermore a mediator of epigenetic regulation [13]. The overexpression of ANRIL moreover causes accelerated proliferation and increased adhesion, as well as decreased apoptosis [205], both of which are key mechanisms of atherogenesis [205].

The lncRNAs FOXF1 adjacent non-coding developmental regulatory RNA (FENDRR) and Braveheart partake in defining the gene transcription program responsible for heart development and cardiomyocyte differentiation, respectively, which indicates they may also be involved in heart failure $[211,212]$.

\section{Discussion and limitations}

To our knowledge, no epigenetically active agents or drugs targeting histone acetylation and/or methylation have thus far entered clinical trials for CVD, nor have any of the latter been approved by the FDA (US Food and Drug Administration). Data on the potential use of epigenetically active compounds concerning these pathologies are, in fact, merely provisional. The complex relationship between epigenetic regulation and CVD development clearly demands further studies.

Epidemiological and clinical studies have shown that lifestyle modifications including nutritional habits and exercise are first protective measures for reducing the risk of CVD. Nutritional factors in particular are essential for preventing cardiovascular diseases. This comprises both avoiding undesirable food supplements, such as high concentrations of salt and low-density lipoproteins, while simultaneously emphasizing nutritional ingredients with beneficial health effects. Food components such as polyphenols, cocoa, and folic acid are known to affect epigenetic signaling pathways including DNA methylation, whereas it should be kept in mind that excessive 
application of folic acid significantly increases the risk of carcinoma.

Although clinical practice does not yet use epigenetically active molecules in the therapy of atherosclerosisrelated CVD, currently available therapies, such as those using statins to promote epigenetic-based control in CVD prevention through histone modifications, are already moving towards an exploitation of these mechanisms.

While it has been more than 20 years since NO was identified as an endogenous agent produced by the cardiovascular system, until recently attempts to create acceptable therapeutic measures for the modulation of endogenous NO activity or production have not progressed much. NO and its signaling responses possess complex features of chemistry, biochemistry, and molecular biology. The development of targeted therapies for NO delivery or agents that enhance endogenous $\mathrm{NO}$ production is intrinsically difficult and the optimal supplemental therapies to significantly increase the positive effects of NO donors or endogenous NO are equally difficult to determine. Thus, all of these issues connected to an epigenetic treatment of CVD require additional clinical study [135].

Non-coding RNAs were found to be important in the pathogenesis of cardiovascular disease and also offer the possibility of operating as diagnostic and prognostic biomarkers [213]. Recent studies-though limited to animal models-have suggested that miRNA inhibition could be an effective therapeutic approach in CVD. Several classes of RNA therapeutics are currently under clinical development by biotechnology companies, including antisense oligonucleotides as well as microRNA mimetics and inhibitors.

The use of miRNA and their targets as diagnostic markers or as therapeutics for CVD is promising, but has not yet been realized. As each miRNA may posttranscriptionally regulate 100 different mRNAs, it is difficult to connect any particular miRNA to a specific disease $[13,214]$. For this reason, it would be preferable to restrict changes in miRNA levels to diseased cells. While the stable inhibition of target miRNAs in specific cell types cannot be achieved through any methodical means currently available, the future is likely to hold some promising opportunities [13].

Further studies are necessary to improve our understanding of the involvement of lncRNA in regulating gene expression changes underlying heart failure, for example. Through the data won from such studies, it could be possible to develop specific therapeutic strategies for heart failure, for example, on the basis of interference with lncRNA pathways. The role of IncRNAs (e.g., FENDRR, Braveheart) in heart development is now emerging. lncRNA mechanisms may prove successful in preventing and treating different CVD [210].

\section{Conclusions}

Cardiovascular diseases confront mankind with vast and daunting health and financial burdens. Improving preventive and therapeutic measures against them is becoming increasingly necessary. Research efforts should particularly aim at the primary prevention of CVD. There is a promise for enhancing the therapeutic armamentarium against a variety of cardiovascular diseases, particularly as cardiovascular tissues are now being targeted with epigenetic therapies.

\section{Abbreviations}

ANRIL: anti-sense non-coding RNA in the INK4 locus; ASOs: anti-sense oligonucleotides; CHD: coronary heart disease; CVD: cardiovascular disease; DAC: 5-aza-2-deoxycytidinedemethylating agent; DNMT: DNA

methyltransferase; eNOS: endothelial nitric oxide synthase; GATA4: GATA binding protein 4; HAT: histone acetyltransferase; HDAC: histone deacetylase; HDL: high-density lipoprotein; LDL: low-density lipoprotein; LNAs: locked nucleic acids; IncRNAs: long non-coding RNAs; miRNA: microRNA; NO: nitric oxide; TSA: trichostatin.

\section{Competing interests}

The author declares that she has no competing interests.

\section{Acknowledgements}

We acknowledge support by Deutsche Forschungsgemeinschaft and Open Access Publishing Fund of University of Tuebingen.

Received: 3 August 2015 Accepted: 6 January 2016

Published online: 15 January 2016

\section{References}

1. Community research and development information service. http://www. cordis.europa.eu/home_en.html. Accessed 14 June 2015

2. Mozaffarian D, Benjamin EJ, Go AS, Arnett DK, Blaha MJ, Cushman M, et al. Heart disease and stroke statistics - 2015 update: a report from the American Heart Association. Circulation. 2015;131(4):e29-322. Epub 2014/12/19.

3. Lloyd-Jones D, Adams RJ, Brown TM, Carnethon M, Dai S, De Simone G, et al. Heart disease and stroke statistics - 2010 update: a report from the American Heart Association. Circulation. 2010;121(7):e46-e215. Epub 2009/12/19.

4. Mathers CD, Loncar D. Projections of global mortality and burden of disease from 2002 to 2030. PLoS Med. 2006:3(11):e442. Epub 2006/11/30.

5. Halfon N, Hochstein M. Life course health development: an integrated framework for developing health, policy, and research. Milbank Q. 2002; 80(3):433-79. iii. Epub 2002/09/18.

6. Ben-Shlomo Y, Kuh D. A life course approach to chronic disease epidemiology: conceptual models, empirical challenges and interdisciplinary perspectives. Int J Epidemiol. 2002;31(2):285-93. Epub 2002/05/01.

7. Wang D, He Y, Li Y, Luan D, Zhai F, Yang X, et al. Joint association of dietary pattern and physical activity level with cardiovascular disease risk factors among Chinese men: a cross-sectional study. PLoS One. 2013;8(6):e66210. Epub 2013/07/11.

8. Chomistek AK, Manson JE, Stefanick ML, Lu B, Sands-Lincoln M, Going SB, et al. Relationship of sedentary behavior and physical activity to incident cardiovascular disease: results from the Women's Health Initiative. J Am Coll Cardiol. 2013;61(23):2346-54. Epub 2013/04/16.

9. Abi Khalil C, Roussel R, Mohammedi K, Danchin N, Marre M. Cause-specific mortality in diabetes: recent changes in trend mortality. Eur J Prev Cardiol. 2012;19(3):374-81. Epub 2012/09/20.

10. Montgomery RL, Hullinger TG, Semus HM, Dickinson BA, Seto AG, Lynch JM, et al. Therapeutic inhibition of miR-208a improves cardiac function and survival during heart failure. Circulation. 2011;124(14):1537-47. Epub 2011/09/09.

11. Schleithoff C, Voelter-Mahlknecht S, Dahmke IN, Mahlknecht U. On the epigenetics of vascular regulation and disease. Clin epigenetics. 2012;4(1):7. Epub 2012/05/25

12. Matouk CC, Marsden PA. Epigenetic regulation of vascular endothelial gene expression. Circ Res. 2008;102(8):873-87. Epub 2008/04/26. 
13. Schiano C, Vietri MT, Grimaldi V, Picascia A, Pascale MR, Napoli C. Epigenetic-related therapeutic challenges in cardiovascular disease. Trends Pharmacol Sci. 2015;36(4):226-35. Epub 2015/03/12.

14. Ehrlich M. DNA hypomethylation in cancer cells. Epigenomics. 2009;1(2):239-59. Epub 2010/05/25

15. Herman JG, Baylin SB. Gene silencing in cancer in association with promoter hypermethylation. N Engl J Med. 2003;349(21):2042-54. Epub 2003/11/25.

16. Duthie SJ. Epigenetic modifications and human pathologies: cancer and CVD. Proc Nutr Soc. 2011;70(1):47-56. Epub 2010/11/12.

17. Turunen MP, Aavik E, Yla-Herttuala S. Epigenetics and atherosclerosis. Biochim Biophys Acta. 2009;1790(9):886-91. Epub 2009/02/24

18. Baccarelli A, Rienstra M, Benjamin EJ. Cardiovascular epigenetics: basic concepts and results from animal and human studies. Circ Cardiovasc Genet. 2010;3(6):567-73. Epub 2010/12/16.

19. Friso S, Pizzolo F, Choi SW, Guarini P, Castagna A, Ravagnani V, et al. Epigenetic control of 11 beta-hydroxysteroid dehydrogenase 2 gene promoter is related to human hypertension. Atherosclerosis. 2008;199(2):323-7. Epub 2008/01/08.

20. Crescenti A, Sola R, Valls RM, Caimari A, Del Bas JM, Anguera A, et al. Cocoa consumption alters the global DNA methylation of peripheral leukocytes in humans with cardiovascular disease risk factors: a randomized controlled trial. PLoS One. 2013;8(6):e65744. Epub 2013/07/11.

21. Feil R, Fraga MF. Epigenetics and the environment: emerging patterns and implications. Nat Rev Genet. 2011;13(2):97-109. Epub 2012/01/05.

22. Corti R, Flammer AJ, Hollenberg NK, Luscher TF. Cocoa and cardiovascular health. Circulation. 2009;119(10):1433-41. Epub 2009/03/18.

23. Visioli F, Bernaert H, Corti R, Ferri C, Heptinstall S, Molinari E, et al. Chocolate, lifestyle, and health. Crit Rev Food Sci Nutr. 2009;49(4):299-312. Epub 2009/02/24.

24. Rimbach G, Melchin M, Moehring J, Wagner AE. Polyphenols from cocoa and vascular health-a critical review. Int J Mol Sci. 2009;10(10):4290-309. Epub 2010/01/09.

25. Willerson JT, Ridker PM. Inflammation as a cardiovascular risk factor. Circulation. 2004;109(21 Suppl 1):I12-10. Epub 2004/06/03.

26. Kaplan RC, Frishman WH. Systemic inflammation as a cardiovascular disease risk factor and as a potential target for drug therapy. Heart Dis. 2001;3(5):326-32. Epub 2002/04/27.

27. Khan N, Khymenets O, Urpi-Sarda M, Tulipani S, Garcia-Aloy M, Monagas M, et al. Cocoa polyphenols and inflammatory markers of cardiovascular disease. Nutr. 2014;6(2):844-80. Epub 2014/02/26.

28. Buijsse B, Feskens EJ, Kok FJ, Kromhout D. Cocoa intake, blood pressure, and cardiovascular mortality: the Zutphen elderly study. Arch Intern Med. 2006;166(4):411-7. Epub 2006/03/01.

29. Janszky I, Mukamal KJ, Ljung R, Ahnve S, Ahlbom A, Hallqvist J. Chocolate consumption and mortality following a first acute myocardial infarction: the Stockholm Heart Epidemiology Program. J Intern Med. 2009;266(3):248-57. Epub 2009/08/28.

30. Kris-Etherton PM, Keen CL. Evidence that the antioxidant flavonoids in tea and cocoa are beneficial for cardiovascular health. Curr Opin Lipidol. 2002;13(1):41-9. Epub 2002/01/16.

31. Ried K, Sullivan TR, Fakler P, Frank OR, Stocks NP. Effect of cocoa on blood pressure. Cochrane Database Syst Rev. 2012;8:CD008893. Epub 2012/08/17.

32. Jia L, Liu X, Bai YY, Li SH, Sun K, He C, et al. Short-term effect of cocoa product consumption on lipid profile: a meta-analysis of randomized controlled trials. Am J Clin Nutr. 2010;92(1):218-25. Epub 2010/05/28.

33. Hooper L, Kroon PA, Rimm EB, Cohn JS, Harvey I, Le Cornu KA, et al. Flavonoids, flavonoid-rich foods, and cardiovascular risk: a meta-analysis of randomized controlled trials. Am J Clin Nutr. 2008;88(1):38-50. Epub 2008/07/11.

34. Hooper L, Kay C, Abdelhamid A, Kroon PA, Cohn JS, Rimm EB, et al. Effects of chocolate, cocoa, and flavan-3-ols on cardiovascular health: a systematic review and meta-analysis of randomized trials. Am J Clin Nutr. 2012;95(3):740-51. Epub 2012/02/04

35. Schroeter $\mathrm{H}$, Heiss C, Balzer J, Kleinbongard P, Keen CL, Hollenberg NK, et al. (-)-Epicatechin mediates beneficial effects of flavanol-rich cocoa on vascular function in humans. Proc Natl Acad Sci U S A. 2006;103(4):1024-9. Epub 2006/01/19.

36. Khan N, Monagas M, Andres-Lacueva C, Casas R, Urpi-Sarda M, Lamuela-Raventos RM, et al. Regular consumption of cocoa powder with milk increases HDL cholesterol and reduces oxidized LDL levels in subjects at high-risk of cardiovascular disease. Nutr Metab Cardiovasc Dis. 2012;22(12):1046-53. Epub 2011/05/10.

37. Baba S, Osakabe N, Kato Y, Natsume M, Yasuda A, Kido T, et al. Continuous intake of polyphenolic compounds containing cocoa powder reduces $L D L$ oxidative susceptibility and has beneficial effects on plasma HDL-cholesterol concentrations in humans. Am J Clin Nutr. 2007:85(3):709-17. Epub 2007/03/09.

38. Osakabe N, Baba S, Yasuda A, Iwamoto T, Kamiyama M, Takizawa T, et al. Daily cocoa intake reduces the susceptibility of low-density lipoprotein to oxidation as demonstrated in healthy human volunteers. Free Radic Res. 2001;34(1):93-9. Epub 2001/03/10.

39. Vita JA. Endothelial function and clinical outcome. Heart. 2005;91(10):1278-9. Epub 2005/09/16.

40. Rein D, Paglieroni TG, Wun T, Pearson DA, Schmitz HH, Gosselin R, et al. Cocoa inhibits platelet activation and function. Am J Clin Nutr. 2000;72(1):30-5. Epub 2000/06/29.

41. Sarria B, Martinez-Lopez S, Sierra-Cinos JL, Garcia-Diz L, Mateos R, Bravo L. Regular consumption of a cocoa product improves the cardiometabolic profile in healthy and moderately hypercholesterolaemic adults. $\mathrm{Br} \mathrm{J}$ Nutr. 2014;111(1):122-34. Epub 2013/07/05

42. Fisher ND, Hollenberg NK. Aging and vascular responses to flavanol-rich cocoa. J Hypertens. 2006;24(8):1575-80. Epub 2006/08/01

43. Heiss C, Finis D, Kleinbongard P, Hoffmann A, Rassaf T, Kelm M, et al. Sustained increase in flow-mediated dilation after daily intake of highflavanol cocoa drink over 1 week. J Cardiovasc Pharmacol. 2007:49(2):74-80. Epub 2007/02/22.

44. Holt RR, Schramm DD, Keen CL, Lazarus SA, Schmitz HH. Chocolate consumption and platelet function. Jama. 2002;287(17):2212-3. Epub 2002/05/01.

45. Murphy KJ, Chronopoulos AK, Singh I, Francis MA, Moriarty H, Pike MJ, et al. Dietary flavanols and procyanidin oligomers from cocoa (Theobroma cacao) inhibit platelet function. Am J Clin Nutr. 2003;77(6):1466-73. Epub 2003/06/07.

46. Innes AJ, Kennedy G, McLaren M, Bancroft AJ, Belch JJ. Dark chocolate inhibits platelet aggregation in healthy volunteers. Platelets. 2003;14(5):325-7. Epub 2003/08/29.

47. Heiss C, Kleinbongard P, Dejam A, Perre S, Schroeter H, Sies H, et al. Acute consumption of flavanol-rich cocoa and the reversal of endothelial dysfunction in smokers. J Am Coll Cardiol. 2005;46(7):1276-83. Epub 2005/10/04.

48. Balzer J, Rassaf T, Heiss C, Kleinbongard P, Lauer T, Merx M, et al. Sustained benefits in vascular function through flavanol-containing cocoa in medicated diabetic patients a double-masked, randomized, controlled trial. J Am Coll Cardiol. 2008;51(22):2141-9. Epub 2008/05/31.

49. Faridi Z, Njike VY, Dutta S, Ali A, Katz DL. Acute dark chocolate and cocoa ingestion and endothelial function: a randomized controlled crossover trial. Am J Clin Nutr. 2008;88(1):58-63. Epub 2008/07/11.

50. Lichtenstein AH, Appel LJ, Brands M, Carnethon M, Daniels S, Franch HA, et al. Summary of American Heart Association Diet and Lifestyle Recommendations revision 2006. Arterioscler Thromb Vasc Biol. 2006;26(10):2186-91. Epub 2006/09/23.

51. Baba S, Natsume M, Yasuda A, Nakamura Y, Tamura T, Osakabe N, et al. Plasma LDL and HDL cholesterol and oxidized LDL concentrations are altered in normo- and hypercholesterolemic humans after intake of different levels of cocoa powder. J Nutr. 2007;137(6):1436-41. Epub 2007/05/22.

52. Mursu J, Voutilainen S, Nurmi T, Rissanen TH, Virtanen JK, Kaikkonen J, et al. Dark chocolate consumption increases HDL cholesterol concentration and chocolate fatty acids may inhibit lipid peroxidation in healthy humans. Free Radic Biol Med. 2004;37(9):1351-9. Epub 2004/09/30.

53. Suzuki H, Tokino $T$, Shinomura $Y$, Imai K, Toyota M. DNA methylation and cancer pathways in gastrointestinal tumors. Pharmacogenomics. 2008:9(12):1917-28. Epub 2008/12/17

54. McNulty H, Pentieva K, Hoey L, Ward M. Homocysteine, B-vitamins and CVD. Proc Nutr Soc. 2008;67(2):232-7. Epub 2008/04/17.

55. Kim J, Kim JY, Song KS, Lee YH, Seo JS, Jelinek J, et al. Epigenetic changes in estrogen receptor beta gene in atherosclerotic cardiovascular tissues and in-vitro vascular senescence. Biochim Biophys Acta. 2007;1772(1):72-80. Epub 2006/11/18.

56. Yang HT, Lee M, Hong KS, Ovbiagele B, Saver JL. Efficacy of folic acid supplementation in cardiovascular disease prevention: an updated metaanalysis of randomized controlled trials. Eur J Intern Med. 2012;23(8):745-54. Epub 2012/08/14.

57. Debreceni B, Debreceni L. Why do homocysteine-lowering B vitamin and antioxidant $E$ vitamin supplementations appear to be ineffective in the prevention of cardiovascular diseases? Cardiovasc Ther. 2012;30(4):227-33. Epub 2011/09/03.

58. Nazki FH, Sameer AS, Ganaie BA. Folate: metabolism, genes, polymorphisms and the associated diseases. Gene. 2014;533(1):11-20. Epub 2013/10/05. 
59. Ciaccio M, Bellia C. Hyperhomocysteinemia and cardiovascular risk: effect of vitamin supplementation in risk reduction. Curr Clin Pharmacol. 2010;5(1):30-6. Epub 2010/03/20.

60. Miller 3rd ER, Juraschek S, Pastor-Barriuso R, Bazzano LA, Appel LJ, Guallar E. Meta-analysis of folic acid supplementation trials on risk of cardiovascular disease and risk interaction with baseline homocysteine levels. Am J Cardiol. 2010;106(4):517-27. Epub 2010/08/10.

61. Cacciapuoti F. Hyper-homocysteinemia: a novel risk factor or a powerful marker for cardiovascular diseases? Pathogenetic and therapeutical uncertainties. J Thromb Thrombolysis. 2011;32(1):82-8. Epub 2011/01/15.

62. Handy DE, Castro R, Loscalzo J. Epigenetic modifications: basic mechanisms and role in cardiovascular disease. Circulation. 2011;123(19):2145-56. Epub 2011/05/18.

63. Lonn E, Yusuf S, Arnold MJ, Sheridan P, Pogue J, Micks M, et al. Homocysteine lowering with folic acid and B vitamins in vascular disease. N Engl J Med. 2006:354(15):1567-77. Epub 2006/03/15.

64. Bonaa KH, Njolstad I, Ueland PM, Schirmer H, Tverdal A, Steigen T, et al. Homocysteine lowering and cardiovascular events after acute myocardial infarction. N Engl J Med. 2006;354(15):1578-88. Epub 2006/03/15.

65. Wald DS, Wald NJ, Morris JK, Law M. Folic acid, homocysteine, and cardiovascular disease: judging causality in the face of inconclusive trial evidence. BMJ (Clin res ed). 2006;333(7578):1114-7. Epub 2006/11/25.

66. Spence JD, Bang H, Chambless LE, Stampfer MJ. Vitamin intervention for stroke prevention trial: an efficacy analysis. Stroke. 2005;36(11):2404-9. Epub 2005/10/22.

67. Rajan S, Wallace Jl, Brodkin KI, Beresford SA, Allen RH, Stabler SP. Response of elevated methylmalonic acid to three dose levels of oral cobalamin in older adults. J Am Geriatr Soc. 2002;50(11):1789-95. Epub 2002/11/02.

68. Wallerath T, Deckert G, Ternes T, Anderson H, Li H, Witte K, et al. Resveratrol, a polyphenolic phytoalexin present in red wine, enhances expression and activity of endothelial nitric oxide synthase. Circulation. 2002;106(13):1652-8. Epub 2002/09/25.

69. Albertoni $\mathrm{G}$, Schor N. Resveratrol plays important role in protective mechanisms in renal disease-mini-review. J Bras Nefrol. 2015;37(1):106-14. Epub 2015/04/30.

70. Arunachalam G, Yao H, Sundar IK, Caito S, Rahman I. SIRT1 regulates oxidant- and cigarette smoke-induced eNOS acetylation in endothelial cells: role of resveratrol. Biochem Biophys Res Commun. 2010;393(1):66-72. Epub 2010/01/28.

71. Frankel EN, Waterhouse AL, Kinsella JE. Inhibition of human LDL oxidation by resveratrol. Lancet. 1993;341(8852):1103-4. Epub 1993/04/24.

72. Reuter S, Gupta SC, Park B, Goel A, Aggarwal BB. Epigenetic changes induced by curcumin and other natural compounds. Gens nutr. 2011;6(2):93-108. Epub 2011/04/26.

73. Bora-Tatar G, Dayangac-Erden D, Demir AS, Dalkara S, Yelekci K, Erdem-Yurter H. Molecular modifications on carboxylic acid derivatives as potent histone deacetylase inhibitors: activity and docking studies. Bioorg Med Chem. 2009;17(14):5219-28. Epub 2009/06/13.

74. Liu HL, Chen Y, Cui GH, Zhou JF. Curcumin, a potent anti-tumor reagent, is a novel histone deacetylase inhibitor regulating B-NHL cell line Raji proliferation. Acta Pharmacol Sin. 2005;26(5):603-9. Epub 2005/04/22.

75. Hu J, Wang Y, Chen Y. Curcumin-induced histone acetylation in malignant hematologic cells. Journal of Huazhong University of Science and Technology Medical sciences $=$ Hua zhong ke ji da xue xue bao Yi xue Ying De wen ban = Huazhong keji daxue xuebao Yixue Yingdewen ban. 2009;29(1):25-8. Epub 2009/02/19

76. Chen Y, Shu W, Chen W, Wu Q, Liu H, Cui G. Curcumin, both histone deacetylase and p300/CBP-specific inhibitor, represses the activity of nuclear factor kappa B and Notch 1 in Raji cells. Basic Clin Pharmacol Toxicol. 2007;101(6):427-33. Epub 2007/10/12.

77. Barnes PJ. Role of HDAC2 in the pathophysiology of COPD. Annu Rev Physiol. 2009;71:451-64. Epub 2008/09/27.

78. Meja KK, Rajendrasozhan S, Adenuga D, Biswas SK, Sundar IK, Spooner G, et al. Curcumin restores corticosteroid function in monocytes exposed to oxidants by maintaining HDAC2. Am J Respir Cell Mol Biol. 2008;39(3):312-23. Epub 2008/04/19.

79. Balasubramanyam K, Varier RA, Altaf M, Swaminathan V, Siddappa NB, Ranga U, et al. Curcumin, a novel p300/CREB-binding protein-specific inhibitor of acetyltransferase, represses the acetylation of histone/nonhistone proteins and histone acetyltransferase-dependent chromatin transcription. J Biol Chem. 2004;279(49):51163-71. Epub 2004/09/24
80. Chen S, Feng B, George B, Chakrabarti R, Chen M, Chakrabarti S. Transcriptional coactivator p300 regulates glucose-induced gene expression in endothelial cells. Am J Physiol Endocrinol Metab. 2010;298(1):E127-37. Epub 2009/11/12.

81. Chiu J, Khan ZA, Farhangkhoee H, Chakrabarti S. Curcumin prevents diabetes-associated abnormalities in the kidneys by inhibiting p300 and nuclear factor-kappaB. Nutrition. 2009;25(9):964-72. Epub 2009/03/10.

82. Lee CW, Lin WN, Lin CC, Luo SF, Wang JS, Pouyssegur J, et al. Transcriptional regulation of VCAM-1 expression by tumor necrosis factoralpha in human tracheal smooth muscle cells: involvement of MAPKs, NFkappaB, p300, and histone acetylation. J Cell Physiol. 2006;207(1):174-86. Epub 2005/11/17.

83. Li HL, Liu C, de Couto G, Ouzounian M, Sun M, Wang AB, et al. Curcumin prevents and reverses murine cardiac hypertrophy. J Clin Invest. 2008;118(3):879-93. Epub 2008/02/23.

84. Singh N, Misra K. Computational screening of molecular targets in Plasmodium for novel non resistant anti-malarial drugs. Bioinformation. 2009;3(6):255-62. Epub 2009/03/04.

85. Taniura H, Sng JC, Yoneda Y. Histone modifications in status epilepticus induced by kainate. Histol Histopathol. 2006;21(7):785-91. Epub 2006/04/07.

86. Ryu H, Smith K, Camelo SI, Carreras I, Lee J, Iglesias AH, et al. Sodium phenylbutyrate prolongs survival and regulates expression of anti-apoptotic genes in transgenic amyotrophic lateral sclerosis mice. J Neurochem. 2005;93(5):1087-98. Epub 2005/06/07.

87. Cui L, Miao J. Cytotoxic effect of curcumin on malaria parasite Plasmodium falciparum: inhibition of histone acetylation and generation of reactive oxygen species. Antimicrob Agents Chemother. 2007;51(2):488-94. Epub 2006/12/06.

88. Rahman I, Marwick J, Kirkham P. Redox modulation of chromatin remodeling: impact on histone acetylation and deacetylation, NFkappaB and pro-inflammatory gene expression. Biochem Pharmacol. 2004;68(6):1255-67. Epub 2004/08/18.

89. Liu Z, Xie Z, Jones W, Pavlovicz RE, Liu S, Yu J, et al. Curcumin is a potent DNA hypomethylation agent. Bioorg Med Chem Lett. 2009;19(3):706-9. Epub 2008/12/30.

90. Medina-Franco JL, Lopez-Vallejo F, Kuck D, Lyko F. Natural products as DNA methyltransferase inhibitors: a computer-aided discovery approach. Mol Divers. 2011;15(2):293-304. Epub 2010/08/11.

91. Sun M, Estrov Z, Ji Y, Coombes KR, Harris DH, Kurzrock R. Curcumin (diferuloylmethane) alters the expression profiles of microRNAs in human pancreatic cancer cells. Mol Cancer Ther. 2008;7(3):464-73. Epub 2008/03/19.

92. Zhang J, Zhang T, Ti X, Shi J, Wu C, Ren X, et al. Curcumin promotes apoptosis in A549/DDP multidrug-resistant human lung adenocarcinoma cells through an miRNA signaling pathway. Biochem Biophys Res Commun. 2010;399(1):1-6. Epub 2010/07/16.

93. Shishodia S, Potdar P, Gairola CG, Aggarwal BB. Curcumin (diferuloylmethane) down-regulates cigarette smoke-induced NF-kappaB activation through inhibition of IkappaBalpha kinase in human lung epithelial cells: correlation with suppression of COX-2, MMP-9 and cyclin D1. Carcinogenesis. 2003;24(7):1269-79. Epub 2003/06/17.

94. Singh S, Aggarwal BB. Activation of transcription factor NF-kappa B is suppressed by curcumin (diferuloylmethane) [corrected]. J Biol Chem. 1995:270(42):24995-5000. Epub 1995/10/20.

95. Wongcharoen W, Phrommintikul A. The protective role of curcumin in cardiovascular diseases. Int J Cardiol. 2009;133(2):145-51. Epub 2009/02/24.

96. Ramirez Bosca A, Soler A, Carrion-Gutierrez MA, Pamies Mira D, Pardo Zapata J, Diaz-Alperi J, et al. An hydroalcoholic extract of Curcuma longa lowers the abnormally high values of human-plasma fibrinogen. Mech Ageing Dev. 2000;114(3):207-10. Epub 2000/05/10.

97. Soni KB, Kuttan R. Effect of oral curcumin administration on serum peroxides and cholesterol levels in human volunteers. Indian J Physiol Pharmacol. 1992;36(4):273-5. Epub 1992/10/01.

98. Pan MH, Lai CS, Wu JC, Ho CT. Epigenetic and disease targets by polyphenols. Curr Pharm Des. 2013;19(34):6156-85. Epub 2013/03/02.

99. Morimoto T, Sunagawa Y, Kawamura T, Takaya T, Wada H, Nagasawa A, et al. The dietary compound curcumin inhibits p300 histone acetyltransferase activity and prevents heart failure in rats. J Clin Invest. 2008;118(3):868-78. Epub 2008/02/23.

100. Guay SP, Legare C, Houde AA, Mathieu P, Bosse Y, Bouchard L. Acetylsalicylic acid, aging and coronary artery disease are associated with ABCA1 DNA methylation in men. Clin epigenetics. 2014;6(1):14. Epub 2014/08/06. 
101. Engel N, Mahlknecht U. Aging and anti-aging: unexpected side effects of everyday medication through sirtuin1 modulation. Int J Mol Med. 2008;21(2):223-32. Epub 2008/01/22

102. Kasai K, Nishiyama N, Izumi Y, Otsuka S, Ishihara A, Yamauchi K. Exposure to 3,3,5-triiodothyronine affects histone and RNA polymerase II modifications, but not DNA methylation status, in the regulatory region of the Xenopus laevis thyroid hormone receptor betaAlpha gene. Biochemical and biophysical research communications. 2015. Epub 2015/09/30

103. Heltweg B, Gatbonton T, Schuler AD, Posakony J, Li H, Goehle S, et al. Antitumor activity of a small-molecule inhibitor of human silent information regulator 2 enzymes. Cancer Res. 2006;66(8):4368-77. Epub 2006/04/19.

104. Bedalov A, Gatbonton T, Irvine WP, Gottschling DE, Simon JA. Identification of a small molecule inhibitor of Sir2p. Proc Natl Acad Sci U S A. 2001;98(26):15113-8. Epub 2001/12/26

105. Grozinger CM, Chao ED, Blackwell HE, Moazed D, Schreiber SL. Identification of a class of small molecule inhibitors of the sirtuin family of NADdependent deacetylases by phenotypic screening. J Biol Chem. 2001;276(42):38837-43. Epub 2001/08/03.

106. Howitz KT, Bitterman KJ, Cohen HY, Lamming DW, Lavu S, Wood JG, et al. Small molecule activators of sirtuins extend Saccharomyces cerevisiae lifespan. Nature. 2003:425(6954):191-6. Epub 2003/08/27.

107. Huang $Y, X U T$, Li J. Role of miR-208 in cardiac fibrosis: prevention or promotion? Arch Med Res. 2014;45(4):356. Epub 2014/04/23.

108. Prado-Uribe MD, Soto-Abraham MV, Mora-Villalpando CJ, Gallardo JM, Bonilla $\mathrm{E}$, Avila $\mathrm{M}$, et al. Role of thyroid hormones and mir-208 in myocardial remodeling in 5/6 nephrectomized rats. Arch Med Res. 2013;44(8):616-22. Epub 2013/11/20.

109. Pantos C, Mourouzis I, Cokkinos DV. Thyroid hormone and cardiac repair/ regeneration: from Prometheus myth to reality? Can J Physiol Pharmacol. 2012:90(8):977-87. Epub 2012/07/06.

110. Ho JJ, Robb GB, Tai SC, Turgeon PJ, Mawji IA, Man HS, et al. Active stabilization of human endothelial nitric oxide synthase mRNA by hnRNP E1 protects against antisense RNA and microRNAs. Mol Cell Biol. 2013;33(10):2029-46. Epub 2013/03/13.

111. Napoli C, Paolisso G, Casamassimi A, Al-Omran M, Barbieri M, Sommese L, et al. Effects of nitric oxide on cell proliferation: novel insights. J Am Coll Cardiol. 2013:62(2):89-95. Epub 2013/05/15.

112. Turgeon PJ, Sukumar AN, Marsden PA. Epigenetics of cardiovascular disease-a new "beat" in coronary artery disease. Med Epigenet. 2014;2(1):37-52. Epub 2014/11/20

113. Won D, Zhu SN, Chen M, Teichert AM, Fish JE, Matouk CC, et al. Relative reduction of endothelial nitric-oxide synthase expression and transcription in atherosclerosis-prone regions of the mouse aorta and in an in vitro model of disturbed flow. Am J Pathol. 2007;171(5):1691-704. Epub 2007/11/06.

114. Wilcox JN, Subramanian RR, Sundell CL, Tracey WR, Pollock JS, Harrison DG, et al. Expression of multiple isoforms of nitric oxide synthase in normal and atherosclerotic vessels. Arterioscler Thromb Vasc Biol. 1997;17(11):2479-88. Epub 1997/12/31.

115. Hajra L, Evans Al, Chen M, Hyduk SJ, Collins T, Cybulsky MI. The NF-kappa B signal transduction pathway in aortic endothelial cells is primed for activation in regions predisposed to atherosclerotic lesion formation. Proc Natl Acad Sci U S A. 2000;97(16):9052-7. Epub 2000/08/02.

116. Stauss HM, Godecke A, Mrowka R, Schrader J, Persson PB. Enhanced blood pressure variability in eNOS knockout mice. Hypertension. 1999;33(6):1359-63. Epub 1999/06/18.

117. Fish JE, Yan MS, Matouk CC, St Bernard R, Ho JJ, Gavryushova A, et al. Hypoxic repression of endothelial nitric-oxide synthase transcription is coupled with eviction of promoter histones. J Biol Chem. 2010;285(2):810-26. Epub 2009/11/03.

118. Fish JE, Matouk CC, Yeboah E, Bevan SC, Khan M, Patil K, et al. Hypoxiainducible expression of a natural cis-antisense transcript inhibits endothelial nitric-oxide synthase. J Biol Chem. 2007;282(21):15652-66. Epub 2007/04/04.

119. Fish JE, Matouk CC, Rachlis A, Lin S, Tai SC, D'Abreo C, et al. The expression of endothelial nitric-oxide synthase is controlled by a cell-specific histone code. J Biol Chem. 2005;280(26):24824-38. Epub 2005/05/05.

120. Chan Y, Fish JE, D'Abreo C, Lin S, Robb GB, Teichert AM, et al. The cell-specific expression of endothelial nitric-oxide synthase: a role for DNA methylation. J Biol Chem. 2004;279(33):35087-100. Epub 2004/ 06/08.

121. Ho JJ, Man HS, Marsden PA. Nitric oxide signaling in hypoxia. J Mol Med (Berl). 2012;90(3):217-31. Epub 2012/02/22.
122. McQuillan LP, Leung GK, Marsden PA, Kostyk SK, Kourembanas S. Hypoxia inhibits expression of eNOS via transcriptional and posttranscriptional mechanisms. Am J Physiol. 1994;267(5 Pt 2):H1921-7. Epub 1994/11/01.

123. Ziesche R, Petkov V, Williams J, Zakeri SM, Mosgoller W, Knofler M, et al. Lipopolysaccharide and interleukin 1 augment the effects of hypoxia and inflammation in human pulmonary arterial tissue. Proc Natl Acad Sci U S A. 1996;93(22):12478-83. Epub 1996/10/29.

124. Yu W, Fu YC, Chen CJ, Wang X, Wang W. SIRT1: a novel target to prevent atherosclerosis. J Cell Biochem. 2009;108(1):10-3. Epub 2009/06/30.

125. Ota H, Akishita M, Eto M, lijima K, Kaneki M, Ouchi Y. Sirt1 modulates premature senescence-like phenotype in human endothelial cells. J Mol Cell Cardiol. 2007;43(5):571-9. Epub 2007/10/06.

126. Mattagajasingh I, Kim CS, Naqvi A, Yamamori T, Hoffman TA, Jung SB, et al. SIRT1 promotes endothelium-dependent vascular relaxation by activating endothelial nitric oxide synthase. Proc Natl Acad Sci U S A. 2007;104(37):14855-60. Epub 2007/09/06.

127. Libby P, Ridker PM, Hansson GK. Progress and challenges in translating the biology of atherosclerosis. Nature. 2011;473(7347):317-25. Epub 2011/05/20.

128. Barres R, Osler ME, Yan J, Rune A, Fritz T, Caidahl K, et al. Non-CpG methylation of the PGC-1alpha promoter through DNMT3B controls mitochondrial density. Cell Metab. 2009;10(3):189-98. Epub 2009/09/03.

129. Udali S, Guarini P, Moruzzi S, Choi SW, Friso S. Cardiovascular epigenetics: from DNA methylation to microRNAs. Mol Aspects Med. 2013;34(4):883-901. Epub 2012/09/18.

130. Granger A, Abdullah I, Huebner F, Stout A, Wang T, Huebner T, et al. Histone deacetylase inhibition reduces myocardial ischemia-reperfusion injury in mice. FASEB J. 2008;22(10):3549-60. Epub 2008/07/09.

131. Napoli C, Crudele V, Soricelli A, Al-Omran M, Vitale N, Infante T, et al. Primary prevention of atherosclerosis: a clinical challenge for the reversal of epigenetic mechanisms? Circulation. 2012;125(19):2363-73. Epub 2012/05/16.

132. Krishna SM, Dear A, Craig JM, Norman PE, Golledge J. The potential role of homocysteine mediated DNA methylation and associated epigenetic changes in abdominal aortic aneurysm formation. Atherosclerosis. 2013;228(2):295-305. Epub 2013/03/19.

133. Kim GH, Ryan JJ, Archer SL. The role of redox signaling in epigenetics and cardiovascular disease. Antioxid Redox Signal. 2013;18(15):1920-36. Epub 2013/03/14.

134. Sato N, Maehara N, Su GH, Goggins M. Effects of 5-aza-2'-deoxycytidine on matrix metalloproteinase expression and pancreatic cancer cell invasiveness. J Natl Cancer Inst. 2003;95(4):327-30. Epub 2003/02/20.

135. Ignarro $L$, Napoli C, Loscalzo J. Nitric oxide donors and cardiovascular agents modulating the bioactivity of nitric oxide: an overview. Circ Res. 2002;90(1):21-8. Epub 2002/01/12.

136. Galkina E, Ley K. Immune and inflammatory mechanisms of atherosclerosis ${ }^{*}$ ). Annu Rev Immunol. 2009;27:165-97. Epub 2009/03/24.

137. Tabet F, Palmisano BT, Taylor RC, Toth CL, Shoucri BM, Vickers KC LS, et al. MicroRNA-223 coordinates cholesterol homeostasis. Proc Natl Acad Sci U S A. 2014:111:14518-23.

138. Ramirez CM, Davalos A, Goedeke L, Salerno AG, Warrier N, Cirera-Salinas D, et al. MicroRNA-758 regulates cholesterol efflux through posttranscriptional repression of ATP-binding cassette transporter A1. Arterioscler Thromb VasC Biol. 2011:31(11):2707-14. Epub 2011/09/03.

139. Vinod M, Chennamsetty I, Colin S, Belloy L, De Paoli F, Schaider H, et al. miR-206 controls LXRalpha expression and promotes LXR-mediated cholesterol efflux in macrophages. Biochim Biophys Acta. 2014;1841(6):82735. Epub 2014/03/08.

140. Zhang E, Wu Y. MicroRNAs: important modulators of oxLDL-mediated signaling in atherosclerosis. J Atheroscler Thromb. 2013;20(3):215-27. Epub 2012/10/16

141. Martin MM, Lee EJ, Buckenberger JA, Schmittgen TD, Elton TS. MicroRNA155 regulates human angiotensin II type 1 receptor expression in fibroblasts. J Biol Chem. 2006;281(27):18277-84. Epub 2006/05/06.

142. Schober A, Nazari-Jahantigh M, Wei Y, Bidzhekov K, Gremse F, Grommes J, et al. MicroRNA-126-5p promotes endothelial proliferation and limits atherosclerosis by suppressing DIk1. Nat Med. 2014;20(4):368-76. Epub 2014/03/04

143. Zhao W, Hu W, Wang X, Xia N, Hu Q, Zhou H. A traditional Chinese medicine, Lujiao prescription, as a potential therapy for hypertrophic cardiomyocytes by acting on histone acetylation. J Chin Med Assoc. 2015 Epub 2015/04/29 
144. Ooi JY, Tuano NK, Rafehi H, Gao XM, Ziemann M, Du XJ, et al. HDAC inhibition attenuates cardiac hypertrophy by acetylation and deacetylation of target genes. Epigenetics. 2015;10(5):418-30. Epub 2015/05/06.

145. Vanhaecke TPP, Elaut G, Rogiers V. Trichostatin A-like hydroxamate histone deacetylase inhibitors as therapeutic agents: toxicological point of view. Curr Med Chem. 2004;12:1629-43.

146. Kar S, Sengupta D, Deb M, Shilpi A, Parbin S, Rath SK, et al. Expression profiling of DNA methylation-mediated epigenetic gene-silencing factors in breast cancer. Clin epigenetics. 2014;6(1):20. Epub 2014/12/06.

147. Rossig L, Li H, Fisslthaler B, Urbich C, Fleming I, Forstermann U, et al. Inhibitors of histone deacetylation downregulate the expression of endothelial nitric oxide synthase and compromise endothelial cell function in vasorelaxation and angiogenesis. Circ Res. 2002;91(9):837-44. Epub 2002/11/02.

148. Kuhl H. Kardiovaskuäre Protektion durch Östrogen/Gestagen-Substitution. Deutsches Ärzteblatt. 1996;93(17):A-1116-9.

149. Zhang L, Qin X, Zhao Y, Fast L, Zhuang S, Liu P, et al. Inhibition of histone deacetylases preserves myocardial performance and prevents cardiac remodeling through stimulation of endogenous angiomyogenesis. J Pharmacol Exp Ther. 2012;341(1):285-93. Epub 2012/01/25.

150. Debreceni B, Debreceni L. The role of homocysteine-lowering Bvitamins in the primary prevention of cardiovascular disease. Cardiovasc Ther. 2014;32(3):130-8. Epub 2014/02/28.

151. Liu XL, Zhang PF, Ding SF, Wang $Y$, Zhang $M$, Zhao YX, et al. Local gene silencing of monocyte chemoattractant protein-1 prevents vulnerable plaque disruption in apolipoprotein E-knockout mice. PLoS One. 2012;7(3):e33497. Epub 2012/03/20.

152. Choi JH, Nam KH, Kim J, Baek MW, Park JE, Park HY, et al. Trichostatin A exacerbates atherosclerosis in low density lipoprotein receptor-deficient mice. Arterioscler Thromb Vasc Biol. 2005;25(11):2404-9. Epub 2005/09/06.

153. Okamoto H, Fujioka Y, Takahashi A, Takahashi T, Taniguchi T, Ishikawa Y, et al. Trichostatin A, an inhibitor of histone deacetylase, inhibits smooth muscle cell proliferation via induction of p21(WAF1). J Atheroscler Thromb. 2006;13(4):183-91. Epub 2006/08/16.

154. Bekkering S, Quintin J, Joosten LA, van der Meer JW, Netea MG, Riksen NP. Oxidized low-density lipoprotein induces long-term proinflammatory cytokine production and foam cell formation via epigenetic reprogramming of monocytes. Arterioscler Thromb Vasc Biol. 2014;34(8):1731-8. Epub 2014/06/07.

155. Harper CR, Jacobson TA. The broad spectrum of statin myopathy: from myalgia to rhabdomyolysis. Curr Opin Lipidol. 2007;18(4):401-8. Epub 2007/07/11.

156. Hennessy EJ, Moore KJ. Using microRNA as an alternative treatment for hyperlipidemia and cardiovascular disease: cardio-miRs in the pipeline. J Cardiovasc Pharmacol. 2013;62(3):247-54. Epub 2013/06/08.

157. Kaikkonen MU, Lam MT, Glass CK. Non-coding RNAs as regulators of gene expression and epigenetics. Cardiovasc Res. 2011;90(3):430-40. Epub 2011/05/12

158. Friedman RC, Farh KK, Burge CB, Bartel DP. Most mammalian mRNAs are conserved targets of microRNAs. Genome Res. 2009;19(1):92-105. Epub 2008/10/29.

159. Romaine SP, Tomaszewski M, Condorelli G, Samani NJ. MicroRNAs in cardiovascular disease: an introduction for clinicians. Heart. 2015;101(12):921-8. Epub 2015/03/31.

160. Rayner KJ, Esau CC, Hussain FN, McDaniel AL, Marshall SM, van Gils JM, et al. Inhibition of miR-33a/b in non-human primates raises plasma HDL and lowers VLDL triglycerides. Nature. 2011;478(7369):404-7. Epub 2011/10/21.

161. Hullinger TG, Montgomery RL, Seto AG, Dickinson BA, Semus HM, Lynch JM, et al. Inhibition of miR-15 protects against cardiac ischemic injury. Circ Res. 2012;110(1):71-81. Epub 2011/11/05

162. van Rooij E, Sutherland LB, Liu N, Williams AH, McAnally J, Gerard RD, et al. A signature pattern of stress-responsive microRNAs that can evoke cardiac hypertrophy and heart failure. Proc Natl Acad Sci U S A. 2006;103(48):18255-60. Epub 2006/11/17.

163. Latronico MV, Condorelli G. MicroRNAs and cardiac pathology. Nat Rev Cardiol. 2009;6(6):419-29. Epub 2009/05/13.

164. Soifer HS, Rossi JJ, Saetrom P. MicroRNAs in disease and potential therapeutic applications. Mol Ther. 2007;15(12):2070-9. Epub 2007/09/20.

165. Bernardo BC, Gao XM, Winbanks CE, Boey EJ, Tham YK, Kiriazis $H$, et al. Therapeutic inhibition of the miR-34 family attenuates pathological cardiac remodeling and improves heart function. Proc Natl Acad Sci U S A. 2012;109(43):17615-20. Epub 2012/10/11.

166. van Rooij E, Sutherland LB, Thatcher JE, DiMaio JM, Naseem RH, Marshall WS, et al. Dysregulation of microRNAs after myocardial infarction reveals a role of miR-29 in cardiac fibrosis. Proc Natl Acad Sci U S A. 2008;105(35):13027-32. Epub 2008/08/30.

167. Thum T, Gross C, Fiedler J, Fischer T, Kissler S, Bussen M, et al. MicroRNA-21 contributes to myocardial disease by stimulating MAP kinase signalling in fibroblasts. Nature. 2008;456(7224):980-4. Epub 2008/12/02.

168. Patrick DM, Montgomery RL, Qi X, Obad S, Kauppinen S, Hill JA, et al. Stress-dependent cardiac remodeling occurs in the absence of microRNA-21 in mice. J Clin Invest. 2010;120(11):3912-6. Epub 2010/10/28.

169. Morrisey EE. The magic and mystery of miR-21. J Clin Invest. 2010;120(11):3817-9. Epub 2010/10/28

170. Sun $X$, Feinberg MW. Knocking out viral myocarditis: reality or a miRage? Circ Res. 2012;111(4):388-91. Epub 2012/08/04

171. Corsten MF, Papageorgiou A, Verhesen W, Carai P, Lindow M, Obad S, et al. MicroRNA profiling identifies microRNA-155 as an adverse mediator of cardiac injury and dysfunction during acute viral myocarditis. Circ Res. 2012;111(4):415-25. Epub 2012/06/21.

172. Caruso P, Dempsie $Y$, Stevens HC, McDonald RA, Long L, Lu R, et al. A role for miR-145 in pulmonary arterial hypertension: evidence from mouse models and patient samples. Circ Res. 2012;111(3):290-300. Epub 2012/06/21.

173. Seok HY, Chen J, Kataoka M, Huang ZP, Ding J, Yan J, et al. Loss of microRNA-155 protects the heart from pathological cardiac hypertrophy. Circ Res. 2014;114(10):1585-95. Epub 2014/03/25.

174. Zernecke A, Bidzhekov K, Noels H, Shagdarsuren E, Gan L, Denecke B, et al. Delivery of microRNA-126 by apoptotic bodies induces CXCL12-dependent vascular protection. Sci Signal. 2009;2(100):ra81. Epub 2009/12/10.

175. Harris TA, Yamakuchi M, Ferlito M, Mendell JT, Lowenstein CJ. MicroRNA-126 regulates endothelial expression of vascular cell adhesion molecule 1. Proc Natl Acad Sci U S A. 2008;105(5):1516-21. Epub 2008/01/30

176. Menghini $R$, Casagrande $V$, Cardellini M, Martelli E, Terrinoni A, Amati $F$, et al. MicroRNA 217 modulates endothelial cell senescence via silent information regulator 1. Circulation. 2009;120(15):1524-32. Epub 2009/09/30.

177. Zhao $Y$, Samal E, Srivastava D. Serum response factor regulates a muscle-specific microRNA that targets Hand2 during cardiogenesis. Nature. 2005:436(7048):214-20. Epub 2005/06/14.

178. Zhao Y, Ransom JF, Li A, Vedantham V, von Drehle M, Muth AN, et al. Dysregulation of cardiogenesis, cardiac conduction, and cell cycle in mice lacking miRNA-1-2. Cell. 2007;129(2):303-17. Epub 2007/04/03.

179. Rayner KJ, Sheedy FJ, Esau CC, Hussain FN, Temel RE, Parathath S, et al. Antagonism of miR-33 in mice promotes reverse cholesterol transport and regression of atherosclerosis. J Clin Invest. 2011;121(7):2921-31. Epub 2011/06/08

180. Takahashi Y, Satoh M, Minami Y, Tabuchi T, Itoh T, Nakamura M. Expression of $\mathrm{miR}-146 \mathrm{a} / \mathrm{b}$ is associated with the Toll-like receptor 4 signal in coronary artery disease: effect of renin-angiotensin system blockade and statins on miRNA-146a/b and Toll-like receptor 4 levels. Clin Sci (Lond). 2010:119(9):395-405. Epub 2010/06/08.

181. Athyros VG, Katsiki N, Karagiannis A, Mikhailidis DP. Combination of statin plus renin angiotensin system inhibition for the prevention or the treatment of atherosclerotic cardiovascular disease. Curr Pharm Des. 2014:20(40):6299-305. Epub 2014/06/24.

182. Dimmeler S, Zeiher AM. Circulating microRNAs: novel biomarkers for cardiovascular diseases? Eur Heart J. 2010;31(22):2705-7. Epub 2010/07/08

183. Fichtlscherer S, De Rosa S, Fox H, Schwietz T, Fischer A, Liebetrau C, et al. Circulating microRNAs in patients with coronary artery disease. Circ Res. 2010;107(5):677-84. Epub 2010/07/03.

184. Wang R, Li N, Zhang Y, Ran Y, Pu J. Circulating microRNAs are promising novel biomarkers of acute myocardial infarction. Intern Med. 2011;50(17):1789-95. Epub 2011/09/02.

185. D'Alessandra Y, Devanna P, Limana F, Straino S, Di Carlo A, Brambilla PG et al. Circulating microRNAs are new and sensitive biomarkers of myocardial infarction. Eur Heart J. 2010:31(22):2765-73. Epub 2010/06/11.

186. Ebert MS, Neilson JR, Sharp PA. MicroRNA sponges: competitive inhibitors of small RNAs in mammalian cells. Nat Methods. 2007:4(9):721-6. Epub 2007/08/19.

187. Visone R, Croce CM. MiRNAs and cancer. Am J Pathol. 2009:174(4):1131-8. Epub 2009/03/07 
188. Tsuda N, Ishiyama S, Li Y, loannides CG, Abbruzzese JL, Chang DZ. Synthetic microRNA designed to target glioma-associated antigen 1 transcription factor inhibits division and induces late apoptosis in pancreatic tumor cells. Clin Cancer Res. 2006:12(21):6557-64. Epub 2006/11/07.

189. Broderick JA, Zamore PD. MicroRNA therapeutics. Gene Ther. 2011;18(12): 1104-10. Epub 2011/04/29.

190. Aartsma-Rus A, van Vliet L, Hirschi M, Janson AA, Heemskerk $H$, de Winter CL, et al. Guidelines for antisense oligonucleotide design and insight into splicemodulating mechanisms. Mol Ther. 2009;17(3):548-53. Epub 2008/09/25.

191. Baker BF, Lot SS, Condon TP, Cheng-Flournoy S, Lesnik EA, Sasmor HM, et al. 2'-O-(2-Methoxy)ethyl-modified anti-intercellular adhesion molecule 1 (ICAM-1) oligonucleotides selectively increase the ICAM-1 mRNA level and inhibit formation of the ICAM-1 translation initiation complex in human umbilical vein endothelial cells. J Biol Chem. 1997;272(18):11994-2000. Epub 1997/05/02.

192. Chan JH, Lim S, Wong WS. Antisense oligonucleotides: from design to therapeutic application. Clin Exp Pharmacol Physiol. 2006;33(5-6):533-40. Epub 2006/05/17.

193. Gouni-Berthold I, Berthold HK. Mipomersen and lomitapide: two new drugs for the treatment of homozygous familial hypercholesterolemia. Atheroscler Suppl. 2015;18:28-34. Epub 2015/05/06.

194. Bell DA, Hooper AJ, Burnett JR. Mipomersen, an antisense apolipoprotein B synthesis inhibitor. Expert Opin Investig Drugs. 2011;20(2):265-72. Epub 2011/01/08.

195. Gebhard C, Huard G, Kritikou EA, Tardif JC. Apolipoprotein B antisense inhibition—update on mipomersen. Curr Pharm Des. 2013;19(17):3132-42. Epub 2013/01/16.

196. Vogt A, Parhofer KG. The potential of mipomersen, an ApoB synthesis inhibitor, to reduce necessity for LDL-apheresis in patients with heterozygous familial hypercholesterolemia and coronary artery disease. Expert Opin Pharmacother. 2013;14(6):691-7. Epub 2013/03/13.

197. Exiquon. What are IncRNAs? http://www.exiqon.com/Incrna. Accessed 17 June 2015.

198. Strahl BD, Allis CD. The language of covalent histone modifications. Nature. 2000;403(6765):41-5. Epub 2000/01/19.

199. Rinn JL, Chang HY. Genome regulation by long noncoding RNAs. Annu Rev Biochem. 2012;81:145-66. Epub 2012/06/06.

200. Holdt LM, Teupser D. Recent studies of the human chromosome 9p2 locus, which is associated with atherosclerosis in human populations. Arterioscler Thromb Vasc Biol. 2012;32(2):196-206. Epub 2012/01/20.

201. Holdt LM, Beutner F, Scholz M, Gielen S, Gabel G, Bergert H, et al. ANRIL expression is associated with atherosclerosis risk at chromosome 9p21. Arterioscler Thromb Vasc Biol. 2010;30(3):620-7. Epub 2010/01/09.

202. Hannou SA, Wouters K, Paumelle R, Staels B. Functional genomics of the CDKN2A/B locus in cardiovascular and metabolic disease: what have we learned from GWASs? Trends Endocrinol Metab. 2015;26(4):176-84. Epub 2015/03/07.

203. Burd CE, Jeck WR, Liu Y, Sanoff HK, Wang Z, Sharpless NE. Expression of linear and novel circular forms of an INK4/ARF-associated non-coding RNA correlates with atherosclerosis risk. PLoS Genet. 2010;6(12):e1001233. Epub 2010/12/15.

204. Cunnington MS, Santibanez Koref M, Mayosi BM, Burn J, Keavney B. Chromosome 9p21 SNPs associated with multiple disease phenotypes correlate with ANRIL expression. PLoS Genet. 2010;6(4):e1000899. Epub 2010/04/14.

205. Holdt LM, Hoffmann S, Sass K, Langenberger D, Scholz M, Krohn K, et al. Alu elements in ANRIL non-coding RNA at chromosome 9p21 modulate atherogenic cell functions through trans-regulation of gene networks. PLoS Genet. 2013;9(7):e1003588. Epub 2013/07/19.

206. Jarinova O, Stewart AF, Roberts R, Wells G, Lau P, Naing T, et al. Functional analysis of the chromosome 9p21.3 coronary artery disease risk locus. Arterioscler Thromb Vasc Biol. 2009;29(10):1671-7. Epub 2009/07/14.

207. Johnson AD, Hwang SJ, Voorman A, Morrison A, Peloso GM, Hsu YH, et al. Resequencing and clinical associations of the 9p21.3 region: a comprehensive investigation in the Framingham heart study. Circulation. 2013;127(7):799-810. Epub 2013/01/15.

208. Folkersen L, Kyriakou T, Goel A, Peden J, Malarstig A, Paulsson-Berne G, et al. Relationship between CAD risk genotype in the chromosome 9p21 locus and gene expression. Identification of eight new ANRIL splice variants. PLoS One. 2009;4(11):e7677. Epub 2009/11/06
209. Liu Y, Sanoff HK, Cho H, Burd CE, Torrice C, Mohlke KL, et al. INK4/ARF transcript expression is associated with chromosome 9p21 variants linked to atherosclerosis. PLoS One. 2009;4(4):e5027. Epub 2009/04/04.

210. Papait R, Kunderfranco P, Stirparo GG, Latronico MV, Condorelli G. Long noncoding RNA: a new player of heart failure? J Cardiovasc Transl Res. 2013; 6(6):876-83. Epub 2013/07/10.

211. Grote P, Wittler L, Hendrix D, Koch F, Wahrisch S, Beisaw A, et al. The tissuespecific IncRNA Fendrr is an essential regulator of heart and body wall development in the mouse. Dev Cell. 2013;24(2):206-14. Epub 2013/02/02.

212. Klattenhoff CA, Scheuermann JC, Surface LE, Bradley RK, Fields PA, Steinhauser $\mathrm{ML}$, et al. Braveheart, a long noncoding RNA required for cardiovascular lineage commitment. Cell. 2013;152(3):570-83. Epub 2013/01/29.

213. Mattick JS, Makunin IV. Non-coding RNA. Hum Mol Genet. 2006;15 Spec No 1:R17-29. Epub 2006/05/03

214. Lim LP, Lau NC, Garrett-Engele P, Grimson A, Schelter JM, Castle J, et al. Microarray analysis shows that some microRNAs downregulate large numbers of target mRNAs. Nature. 2005;433(7027):769-73. Epub 2005/02/03.

\section{Submit your next manuscript to BioMed Central and we will help you at every step:}

- We accept pre-submission inquiries

- Our selector tool helps you to find the most relevant journal

- We provide round the clock customer support

- Convenient online submission

- Thorough peer review

- Inclusion in PubMed and all major indexing services

- Maximum visibility for your research

Submit your manuscript at www.biomedcentral.com/submit

) Biomed Central 